\title{
Schwann Cell Myelination
}

\author{
James L. Salzer \\ Department of Neuroscience and Physiology, New York University Neuroscience Institute, New York \\ University School of Medicine, New York, New York 10016 \\ Correspondence: james.salzer@nyumc.org
}

Myelinated nerve fibers are essential for the rapid propagation of action potentials by saltatory conduction. They form as the result of reciprocal interactions between axons and Schwann cells. Extrinsic signals from the axon, and the extracellular matrix, drive Schwann cells to adopt a myelinating fate, whereas myelination reorganizes the axon for its role in conduction and is essential for its integrity. Here, we review our current understanding of the development, molecular organization, and function of myelinating Schwann cells. Recent findings into the extrinsic signals that drive Schwann cell myelination, their cognate receptors, and the downstream intracellular signaling pathways they activate will be described. Together, these studies provide important new insights into how these pathways converge to activate the transcriptional cascade of myelination and remodel the actin cytoskeleton that is critical for morphogenesis of the myelin sheath.

$T^{\mathrm{h}}$ he myelin sheath is a vertebrate evolutionary adaptation that likely enabled development of large, complex nervous systems by promoting rapid, efficient nerve conduction. Based on the appearance during evolution of several key proteins, myelin is thought to have evolved in early gnathostomes in a common glial precursor, which later gave rise to the distinct Schwann cell and oligodendrocyte lineages (Gould et al. 2008; Zalc et al. 2008). Indeed, the overall organization of myelinated axons in the central nervous system (CNS) and peripheral nervous system (PNS) is similar, consistent with their conserved roles in saltatory conduction. However, there are substantial differences in the development and assembly of myelin by Schwann cells and oligodendrocytes. Thus, the extrinsic signals that drive myelination, the transcriptional cascades they activate, and even the cyto- skeletal changes that direct glial membrane wrapping around axons differ. In accordance, diseases of myelin, generally, are restricted to those that affect PNS myelinated fibers (e.g., CMT1) or CNS fibers (e.g., multiple sclerosis [MS], leukodystrophies, etc.).

Here, we focus on the myelinating Schwann cell. Its organization into discrete membrane and cytoplasmic compartments will be described. New insights into the extrinsic signals and intracellular pathways that drive Schwann cell myelination will be highlighted, including pathways that regulate the actin cytoskeleton during myelin morphogenesis and the transcriptional cascade of myelination. Finally, effects of myelinating Schwann cells on axons will be discussed. Several excellent reviews on Schwann cell biology have recently been published (Pereira et al. 2012; Glenn and Talbot

Editors: Ben A. Barres, Marc R. Freeman, and Beth Stevens

Additional Perspectives on Glia available at www.cshperspectives.org

Copyright (C) 2015 Cold Spring Harbor Laboratory Press; all rights reserved; doi: 10.1101/cshperspect.a020529

Cite this article as Cold Spring Harb Perspect Biol 2015;7:a020529 


\section{J.L. Salzer}

2013b; Kidd et al. 2013) and may be consulted for additional details not provided here.

\section{ORGANIZATION AND POLARITY OF THE PNS MYELIN SHEATH}

Myelinating Schwann cells are radially and longitudinally polarized cells (Salzer 2003; Ozcelik et al. 2010; Pereira et al. 2012). With myelination, Schwann cells organize into distinct membrane domains, each with a unique array of proteins, and a communicating set of cytoplasmic compartments (Fig. 1). Longitudinal polarity is evident by the overall organization of the myelinating Schwann cell, and axon, into nodal, paranodal, juxtaparanodal, and internodal compartments. Radial polarity is indicated by the distinct inner (adaxonal) and outer (abaxonal) membrane surfaces, which are present at each end of the cell on opposite sides; interposed between these two membranes domains are the compacted membranes of the myelin sheath.

The adaxonal membrane is separated from the axolemma by a gap of $\sim 15 \mathrm{~nm}$ (the periaxonal space); it is enriched in adhesion molecules and receptors that mediate interactions with cognate ligands on the axon. These maintain the periaxonal space and transduce signals from axonal growth factors, respectively. The

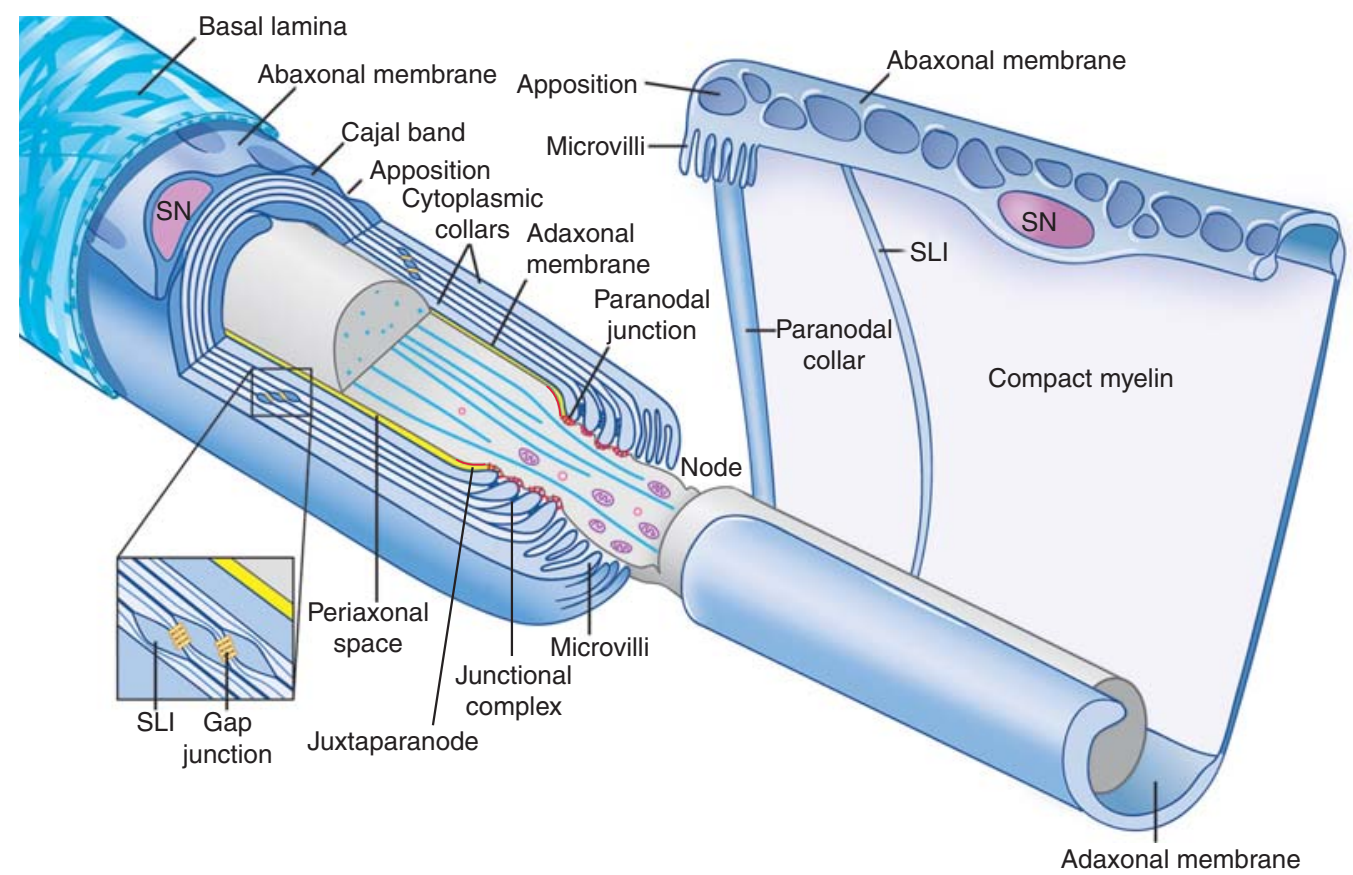

Figure 1. Organization of myelinating Schwann cells. Schematic organization of myelinating Schwann cells (blue) surrounding an axon (gray); the left cell is shown in longitudinal cross section and the right cell is shown unwrapped. Myelinating Schwann cells are surrounded by a basal lamina (illustrated only on the left), which is in direct contact with the abaxonal membrane. The abaxonal compartment contains the Schwann cell nucleus $(\mathrm{SN})$; it is divided into Cajal bands and periodic appositions that form between the abaxonal membrane and outer turn of compact myelin. The Schwann cell adaxonal membrane is separated from the axonal membrane by the periaxonal space (shown in yellow). Compact myelin is interrupted by Schmidt-Lanterman incisures (SLI), which retain cytoplasm and are enriched in the gap and other junctions; a similar autotypic junctional complex of adherens, tight and gap junctions, forms between the apposed membranes of the paranodal loops. Also shown are the paranodal loops and junctions (red) and the Schwann cell microvilli contacting the axon at the node. The axon diameter is reduced in the region of the node and paranodes. (This figure is adapted, with permission, from an original figure in Salzer 2003; modified in Nave 2010.) 
adaxonal membrane is further organized into the paranodal, juxtaparanodal, and internodal domains. The largest such domain is the internode, comprising some $99 \%$ of the length of the myelinating Schwann cell. Glial adhesion molecules present along the internode include the myelin-associated glycoprotein (MAG) and the nectin-like proteins, Necl-2 (CADM1) and Necl-4 (CADM4) (Maurel et al. 2007; Spiegel et al. 2007); the Necls/Cadm are tethered to a 4.1-G-based cytoskeleton. The remaining $1 \%$ corresponds to the nodal region, including the node itself, the flanking paranodes, and juxtaparanodes. Protein components for these domains are discussed in detail elsewhere (Salzer et al. 2008; see also Rasband and Peles 2015).

The outer, abaxonal membrane lies adjacent to and mediates interactions with laminin in the basal lamina, notably the integrins, including $\alpha 6 \beta 1$, which is expressed initially, and $\alpha 6 \beta 4$ and $\beta$ dystroglycan, which are up-regulated with myelination (Einheber et al. 1992; Previtali et al. 2003). Unlike the inner cytoplasmic compartment, which is uniformly spaced, the outer cytoplasmic compartment is interrupted by periodic appositions between the abaxonal membrane and the outer wrap of the compact myelin sheath (Fig. 2). These appositions are enriched in a dystroglycan complex linked via dystrophin-related protein 2 (Drp2) to periaxin, a highly abundant scaffolding protein of myelinating Schwann cells (Sherman et al. 2012b). These appositions delineate a network of anastomosing, cytoplasmic channels, termed Cajal bands (Court et al. 2004). These cytoplasmic channels lie on the outside of the Schwann cell and provide a conduit for centrifugal transport of RNA and proteins originating in the cell soma en route to the paranodal collar (Gould and Mattingly 1990; Court et al. 2004). The outer membrane of the Cajal bands interact with laminin of the basal lamina via the $\beta 1$ integrin (Court et al. 2011b) and a second, distinct dystroglycan complex (Masaki and Matsumura 2010; Walko et al. 2013). Consistent with their proposed role in transport, Cajal bands are enriched in a large array of cytoskeletal proteins, including microtubules, intermediate filaments, and an actin/spectrin complex (Susuki et al. 2011; Kidd et al. 2013; Walko et al. 2013). They also represent sites of localized protein synthesis (Gould and Mattingly 1990), and intracellular signaling via laminin receptors (Heller et al. 2014). Based on their enrichment in caveolae

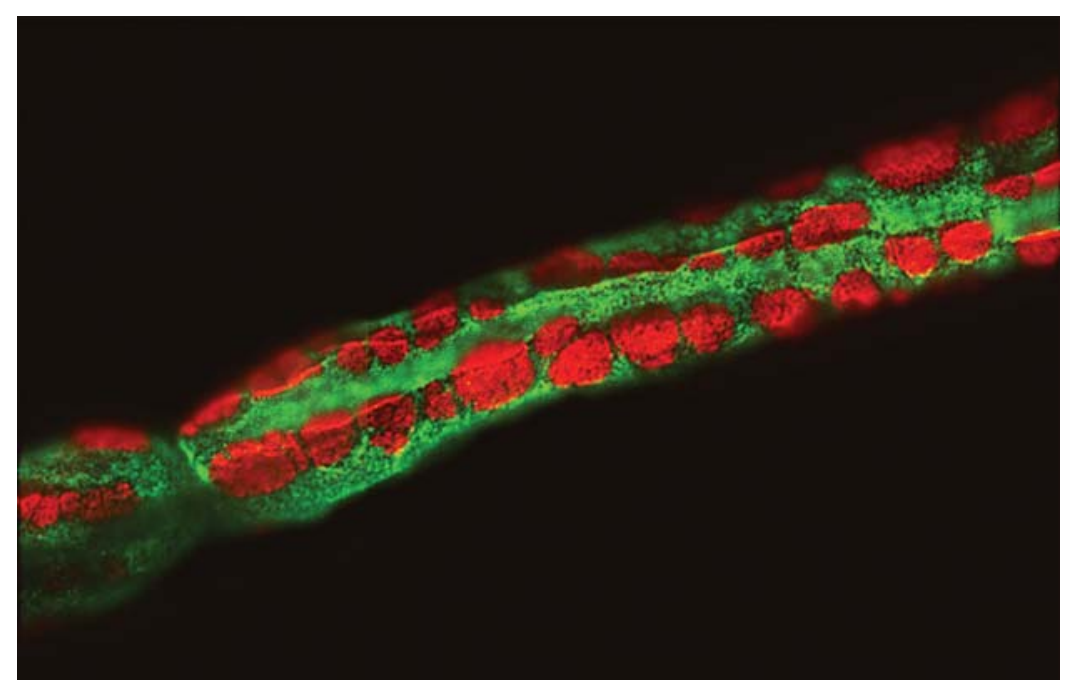

Figure 2. Cajal bands. Fluorescence micrograph showing a portion of a teased, myelinated fiber from adult rat sciatic nerve, the presence of the Cajal bands (green), and the membrane appositions (red) in the abaxonal compartment. Staining shown is for phospho-NDRG1 (green) and $\alpha$-dystroglycan (red) (see Heller et al. 2014 for further details). 
J.L. Salzer

(Mugnaini et al. 1977; Koling 1985; Mikol et al. 1999), they may function in the uptake of metabolites from the extracellular space.

In between these two membranes is the multilamellar, compact myelin sheath, which results from the circumferential wrapping of the Schwann cell plasma membrane. Myelin provides a high-resistance, low-capacitance sheath essential for impulse propagation by saltatory conduction. The myelin sheath itself is comprised of 40 or more lamellae (Peters et al. 1991). Electron micrographs of compact myelin reveal interperiod lines, which represent the appositions of the extracellular leaflets, alternating with major dense lines (MDLs), representing the tight apposition of the cytoplasmic leaflets (Fig. 3). Myelin has a uniquely high- ( 70\%) lipid content for a plasma membrane and is enriched in galactosphingolipids, saturated long-chain fatty acids and, particularly, cholesterol; the latter has an essential role for myelin sheath assembly (Saher and Simons 2010).

Compact myelin is greatly enriched in a very few proteins (Fig. 3); these are likely to be quite stable in the mature sheath with limited turnover akin to the stability of CNS myelin proteins (Toyama et al. 2013). Among these proteins are P0, a transmembrane adhesion molecule of the immunoglobulin gene superfamily, which promotes apposition of the extracellular leaflets via homophilic adhesion (Filbin et al. 1990; Shapiro et al. 1996). P0 requires cholesterol for proper endoplasmic reticulum (ER) export (Saher et al. 2009). Another key protein is maltose-binding protein (MBP), a peripheral membrane protein thought to neutralize the charges of the phospholipids, especially phosphatidylserines (Kidd et al. 2013). MBP and the cytoplasmic segment of $\mathrm{P} 0$, together, promote apposition of the intracellular leaflets to form the MDL (Martini et al. 1995). Other compact myelin proteins include several tetraspanins, notably PMP22, which is frequently mutated in inherited neuropathies (Vallat et al. 1996; Rossor et al. 2013). Recent mass spectroscopy studies, using myelin-enriched fractions, suggest the presence of many additional proteins, some known and others novel (Patzig et al. 2011). These are present at much-reduced levels; characterization of these proteins is as yet incomplete, including whether they are localized to compact myelin or to other sites in the Schwann cell.

Compact myelin is interrupted by the Schmidt-Lanterman incisures, which are interspersed along the internode and most abundant in heavily myelinated, large-diameter fibers. Surprisingly, the clefts often develop after the myelin sheath has substantially formed, arising via extension from the inner or outer collars of cytoplasm by circumferential extension into compact myelin sheath (Small et al. 1987), indicating an active process of decompaction of the myelin lamellae. Their late origin suggests that they do not have an essential role during PNS myelin formation, but rather may assist in its maintenance; this notion is consistent with periaxin mutants that lack clefts and form unstable myelin sheaths (Gillespie et al. 2000).

The clefts have long been thought to provide a conduit for communication between the inner and outer collars of cytoplasm via the presence of gap junctions, which are arrayed between adjacent membranes (Balice-Gordon et al. 1998). Adjacent membranes in the clefts also harbor autotypic adherens junctions (Fannon et al. 1995), tight junctions, and a series of PDZ (PSD95, Dlg1, ZO-1)-domain-containing proteins, including the MAGUKs, which are linked to the $4.1 \mathrm{G}$ cytoskeleton (Terada et al. 2012), and likely, thereby, to F-actin in the clefts (Trapp et al. 1989). Recent studies suggest that the clefts, which are enriched in the tyrosine kinase Src (Terada et al. 2013), are a site of autocrine signaling (Heller et al. 2014), consistent with their rich array of cell junctions. Many of the adhesion molecules present in the adaxonal membrane, that is, MAG and the Necls (Cadms), are also enriched in the clefts (Maurel et al. 2007; Spiegel et al. 2007), suggesting a common topology; interactions of the Cadms likely contribute to the structural integrity of the incisures.

Components of classical polarity complexes are enriched at distinct sites of myelinating Schwann cells (Masaki 2012; Pereira et al. 2012). Notably, Par-3 is enriched in the inner, periaxonal cytoplasmic compartment and in the incisures (Poliak et al. 2002; Chan et al. 

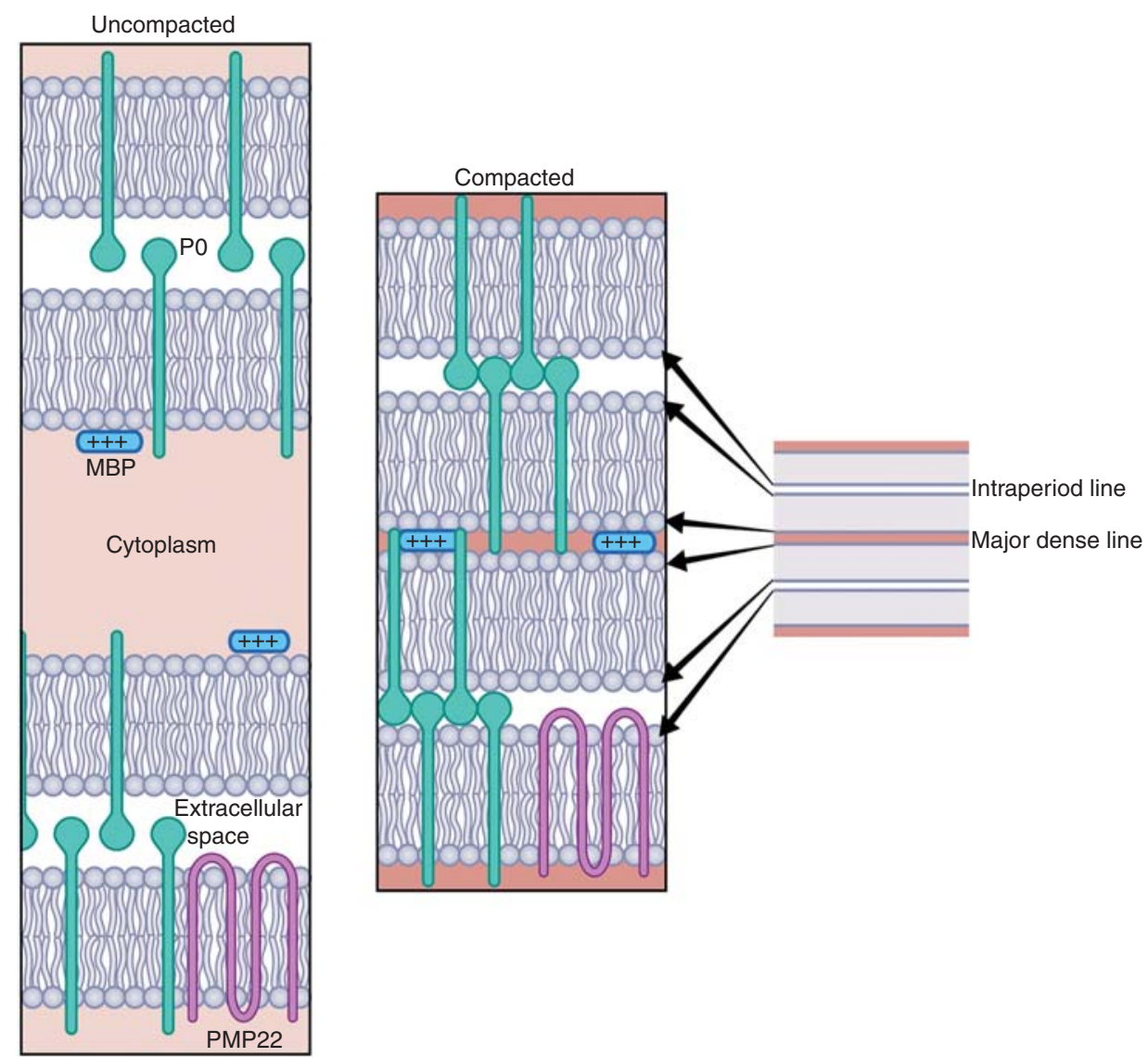

Figure 3. Schematic organization of the compact myelin sheath. Myelin forms, initially, as loose wraps of uncompacted membrane. With the onset of myelin transcription, myelin proteins are up-regulated, including $\mathrm{P} 0$, maltose-binding protein (MBP), and PMP22, which are shown diagrammatically. Compaction is mediated by extracellular interactions of P0 tetramers on one membrane interacting with P0 tetramers on the opposing membrane, shown here only as dimer/dimer interactions for simplicity. Compaction of the cytoplasmic leaflets is mediated by electrostatic interactions of MBP with the phospholipid bilayer supplemented by the interactions with the cytoplasmic tail of P0. Compact myelin appears on electron microscopy (EM) as a major dense line (MDL) (representing tight apposition of the cytoplasmic leaflets) alternating with the intraperiod lines (representing the two apposed extracellular leaflets) as shown.

2006). Par-3 is part of the PAR-3/PAR-6/aPKC complex, which is typically enriched in cell junctions; it is the first polarity complex to become asymmetrically localized in epithelia and regulates the localization of other polarity complexes (Goldstein and Macara 2007). These other complexes include the Scribble/Lethal giant larvae (Lgl)/Discs large (Dlg) complex and the crumbs/Pals/Patj complex; in polarized epithelia, these have a basolateral and apical localization, respectively (Pereira et al. 2012). Compo- nents of these polarity complexes are also expressed in myelinating Schwann cells, members of the Scribble complex are enriched in the abaxonal compartment and Crumbs is enriched, together with Par-3, in the adaxonal domain and SLI (Poliak et al. 2002; Chan et al. 2006; Ozcelik et al. 2010). This organization, together with location of the extracellular matrix, has evoked metaphors to polarized epithelia and to the notion that the adaxonal and abaxonal compartments are functional ortho- 
J.L. Salzer

logs of apical and basolateral domains, respectively (Salzer 2003; Pereira et al. 2012).

Components of these polarity complexes have been implicated in myelin formation. Thus, Schwann cells fail to myelinate sensory neurons in cocultures when Par3 is knocked down by small hairpin RNA (shRNA) (Chan et al. 2006), and defects of myelination are observed when the activity of aPKC, which is regulated by Par3, is likewise reduced (Beirowski et al. 2011). The precise mechanisms that drive the targeting of these complexes to their respective intracellular sites, regulate their activity, their importance during myelination in vivo, and the identity of their downstream effectors are significant questions for future study.

\section{TRANSCRIPTIONAL AND EPIGENETIC REGULATION OF THE MYELIN PHENOTYPE}

The myelin phenotype results from a sequential, feedforward cascade of promyelinating transcription factors (TFs) (see Fig. 4) (Svaren and Meijer 2008). These TFs include Sox2, NF-кB, and Egr1, which are expressed initially. With segregation of axons and myelination, NF- $\kappa$, Pou3f1 (Oct6/SCIP/Tst1), Pou3f2 (Brn2), Sox10, NFATc4, YY1 (Yin Yang), and Egr2/
Krox20 are up-regulated and/or activated (Svaren and Meijer 2008; Kao et al. 2009; He et al. 2010). NF- $\kappa$ B was implicated in regulating myelination in vitro (Nickols et al. 2003); it has a dispensable role in vivo (Morton et al. 2013). During the transition from promyelination to myelination, Pou3f1 and Pou3f2 are turned off and Krox20 is up-regulated. Krox20 expression is promoted by Pou3f1 and Pou3f2 (Jaegle et al. 2003) and NFATc4 and YY1 (Kao et al. 2009; He et al.2010). Sox10 also drives Krox20 expression, cooperatively with NFATc4 (Kao et al. 2009) and by recruiting the Mediator 12 complex, a regulator of transcription initiation and elongation, to the Schwann cell-specific myelin-specific enhancer (MSE) of the Krox20 gene (Weider et al. 2012; Vogl et al. 2013). Another Pou domain TF, Pou6F1 (Brn5), is expressed in myelinating Schwann cells (Wu et al. 2001); its function in promoting or maintaining the myelinating phenotype has not yet been established. Finally, in keeping with the massive up-regulation of lipid synthesis during myelination, sterol regulatory element-binding protein (SREBP, TFs) are upregulated and have an essential role in Schwann cell myelination (Camargo et al. 2009).

Krox20 is considered a master regulator of PNS myelination as, together with the NAB

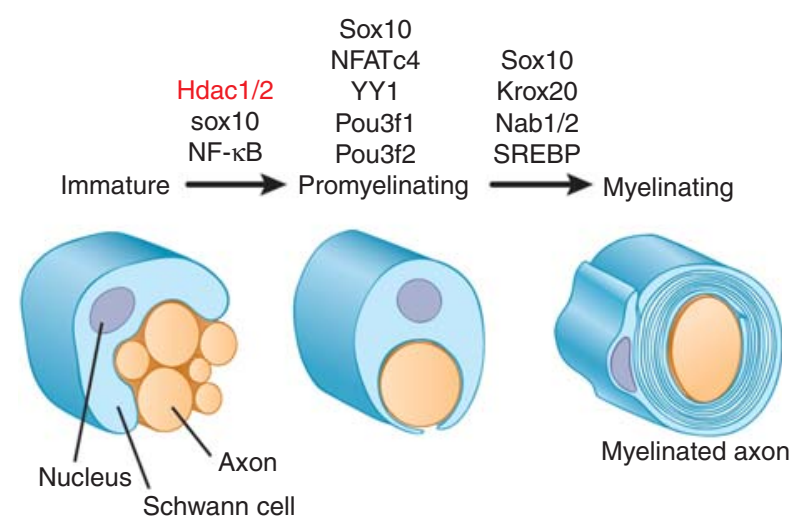

Figure 4. Transcriptional cascade of myelination. Expression of TFs at different stages of the Schwann cell lineage is shown. At the immature stage, expression of Sox 10 and of Hdac1/2 (epigenetic regulators, red) is essential for progression to the promyelinating stage; NF- $\kappa$ B promotes, but is not essential, during the Schwann cell lineage. Progression from the promyelinating to the myelinating phenotype requires Pou3f1 (Oct6) and Pou3f2 (Brn2) for timely advance; Sox10, NFATc4, and YY1 are essential. These latter proteins all promote expression of Krox20, which, together with the interacting Nab proteins, is essential for the expression of the myelinating phenotype. Lipid biosynthesis is up-regulated via SREBP. 
proteins, it drives transcription of myelin structural proteins and biosynthetic components of myelin lipid synthesis (Topilko et al. 1994; Le et al. 2005b). A striking feature of the transcriptional phenotype of a Schwann cell is that it can adopt alternate fates as a myelinating versus a nonmyelinating/Remak Schwann cell. This binary distinction is reinforced via transcriptional cross-repression in which Sox 2 and c-Jun inhibit Krox20 expression, and vice versa (Le et al. 2005a; Parkinson et al. 2008; Jessen et al. 2015). Maintenance of the myelinating phenotype requires the ongoing expression of both Krox20 and Sox10; conditional inactivation of either results in dedifferentiation, which is particularly rapid in the case of Krox20 (Decker et al. 2006; Bremer et al. 2011). This latter result suggests an active transcriptional cascade involving Sox10, likely functioning with Pou3f1 and/ or Pou3f2, to sustain Krox20 expression; these results also imply Krox20 is subject to active turnover.

Recent studies highlight the importance of epigenetic regulation during PNS myelination (Pereira et al. 2012), similar to its essential role in the CNS (Huynh and Casaccia 2013). Epigenetic modifications that regulate gene expression include DNA methylation, posttranslational modifications of nucleosomal histones (e.g., acetylation, methylation, citrullination, etc.), and expression of noncoding RNAs, notably microRNAs (miRNAs) (Huynh and Casaccia 2013). In the case of Schwann cells, several epigenetic modifiers work in concert with Sox10, including the Brahma-associated factor (BAF) complex, a chromatin-remodeling complex that regulates access to DNA (Weider et al. 2013). Loss of Brahma-related gene product (Brg1), the catalytic core of BAF, phenocopies Sox10 conditional knockouts (Finzsch et al. 2010). Sox10 appears to direct the Baf60a-dependent recruitment of BAF complexes to several Sox10 target genes, including Oct6 and Krox20 and thereby enhancing their expression (Weider et al. 2013). Sox10 also interacts with histone deacetylases (HDACs) — enzymes that remove acetyl residues from lysines in histones thereby regulating transcription. In particular, HDAC2 activates the transcriptional program of myelination in synergy with Sox10 (Jacob et al. 2011); the combined loss of HDAC1 and -2 results in the arrest of Schwann cells at the promyelinating stage (Jacob et al. 2011). Finally, miRNAs have been implicated as important, posttranscriptional regulators of myelination (Pereira et al. 2012). This is compellingly indicated by conditional inactivation of DICER in Schwann cells during development, which results in the arrest of Schwann cells at the promyelinating stage (Bremer et al. 2010; Pereira et al. 2010; Yun et al. 2010). An important question is the identity of the extrinsic signals that drives this transcriptional program, and that of axon wrapping.

\section{EXTRINSIC SIGNALS THAT REGULATE MYELINATION: LIGANDS AND RECEPTORS}

There has been substantial progress in identifying the extrinsic signals, their Schwann cell receptors, and the intracellular pathways they regulate that control myelination (Fig. 5). The major and best-characterized extrinsic signals are those presented by the axon and extracellular matrix, that is, neuregulin (NRG) type III and laminin, respectively. Other key signals and receptors that are essential for PNS myelination were more recently identified and include G-coupled protein (Gpr) 126 and Adam22/Lgi4 (Salzer 2012; Glenn and Talbot $2013 \mathrm{~b}$ ). In general, there appears to be a spatiotemporal transition in signals with those originating from the axon, that is, NRG1, activating the adaxonal compartment early on, and those that originate in basal lamina, for example, laminins and collagens, which activate the abaxonal compartment acting with, perhaps, a modest delay (Heller et al. 2014). This is consistent with earlier studies showing that axonal signals direct Schwann cell assembly of the basal lamina during development (Bunge et al. 1982).

\section{Axonal Regulation of Myelination: NRG1 and erbB Receptors}

It has been known for more than 100 years that axons direct their own ensheathment fate, that is, whether Schwann cells ensheath multiple, 


\section{J.L. Salzer}

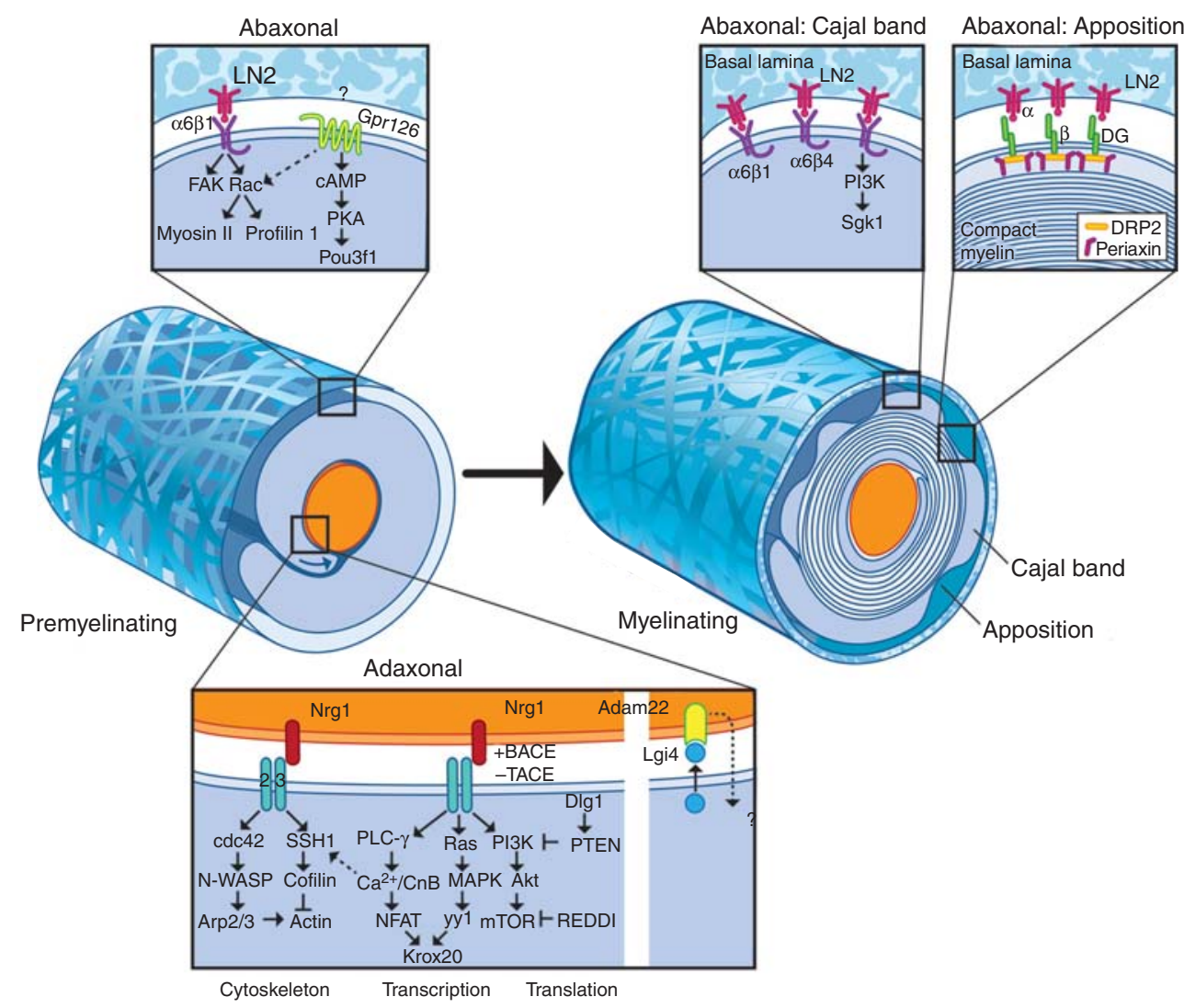

Figure 5. Schematic of extrinsic signals, receptors, and intracellular signaling pathways that regulate myelination. This figure summarizes the key extrinsic signals, their receptors, and the downstream signaling pathways active in the adaxonal and abaxonal compartments. The major axonal signals include type III NRG1 and Adam22 (disintegrin and metalloprotease), which signal via erbB receptors and Lgi4 (leucine-rich glioma inactivated), respectively. NRG1 is subject to protease cleavage that is activating (BACE, $\beta$-secretase) or inactivating (TACE, tumor necrosis factor- $\alpha$-converting enzyme). Major pathways downstream from $\operatorname{erb} B$ signaling include (1) phospholipase C (PLC)- $\gamma$, calcineurin B (CnB), and nuclear factor of activated T cells (NFAT), (2) mitogenactivated protein kinase (MAPK), and (3) PI3K, Akt, and the mammalian target of rapamycin (mTOR). NFATc4 and YY1 drive transcription of Krox20; mTOR is a regulator of cap-dependent protein synthesis. NRG signaling also drives the remodeling of the actin cytoskeleton as shown. In the abaxonal compartment before myelination, laminin signaling activates FAK and Rac to promote radial sorting. Gpr126 regulates cAMP and protein kinase A (PKA) to promote sorting and myelination; its assignment to the abaxonal compartment is tentative and its ligand(s) at the time of this review has not been reported. With maturation, the abaxonal compartment organizes into the cytoplasmic channels, termed Cajal bands, and membrane appositions. Signaling in the Cajal bands is mediated in part via integrins. The membrane apposition is mediated by a complex of dystroglycan, DRP2, and periaxin; the space between the baseline (BL) and the appositions as shown is exaggerated for artistic purposes. See the text for additional details on these pathways. N-WASP, Neuronal Wiskott-Aldrich syndrome protein. 
small axons or segregate and myelinate larger ones (Langley and Anderson 1903). Myelination typically commences around axons that are $\geq 1 \mu \mathrm{m}$ in size (Peters et al. 1991), in agreement with theoretical models that suggest myelination enhances conduction velocity in PNS axons with diameters $\geq 1 \mu \mathrm{m}$ (Rushton 1951). Above this size, myelin sheath thickness and internodal length and, thus, the total myelin membrane expanse, are tightly correlated to the diameter of the axon (Matthews 1968). For sheath thickness, this relationship is measured as the $g$ ratio, that is, axon diameter/total fiber diameter, which is typically close to 0.67 for PNS fibers. Thus, axons not only trigger Schwann cells to myelinate, but also determine the amount of myelin they form.

These considerations led to the hypothesis that a critical axonal diameter triggers Schwann cell myelination, reflecting either the size of the axon (Murray 1968; Friede 1972; Voyvodic 1989) or the quantity of signaling molecules on its surface (Spencer and Weinberg 1978). Alternatively, distinct biochemical signals presented by the axon may dictate its ensheathment fate (Salzer 1995). Work in recent years indicates that axons destined for myelination are both larger and biochemically distinct as they express higher levels of the growth factor, NRG1, which is a key trigger for myelination (Nave and Salzer 2006).

NRG1 is a member of the epidermal growth factor (EGF) superfamily, comprised of a large number of alternatively spliced transmembrane isoforms. Six major classes of NRG1 have been described (types I-VI), which differ in the splicing patterns of the ectodomain; types I-III are the most abundant, with type III being the predominant form on peripheral axons (Mei and Xiong 2008). NRG1, like other members of the EGF superfamily, signals by binding to and activating members of the $\operatorname{erb} B$ family of tyrosine kinase receptors (Mei and Xiong 2008). Schwann cells principally express the erbB2/erbB3 heterodimer (Newbern and Birchmeier 2010).

NRG1 signaling regulates virtually all aspects of the Schwann cell lineage (Newbern and Birchmeier 2010; Jessen et al. 2015). It has also been implicated in the segregation of axons by Schwann cells (Taveggia et al. 2005; Raphael et al. 2011). The first indication that NRG1 is also required for myelination was the hypomyelination of peripheral nerves when NRG1 receptors were conditionally inactivated during late Schwann cell development (Garratt et al. 2000). Subsequently, it was shown that the expression levels of type III NRG1, an abundant membrane-tethered isoform on axons, correlate with the ensheathment fate of axons; thus, axons that will be myelinated express much higher levels of type III NRG1 than do axons in Remak fibers (Taveggia et al. 2005). Importantly, forced expression of type III NRG1 in sympathetic fibers, which are normally unmyelinated, resulted in their myelination in vitro (Taveggia et al. 2005). Haploinsufficiency or full genetic inactivation of NRG1, in particular of the type III isoform, resulted in significant PNS hypomyelination (Michailov et al. 2004; Taveggia et al. 2005; Brinkmann et al. 2008), a reduction in the percentage of myelinated axons and aberrant sorting in Remak fibers (Taveggia et al. 2005). Finally, overexpression of the type III isoform in neurons results in significant hypermyelination, with substantially reduced $g$ ratios $(\mathrm{Mi}-$ chailov et al. 2004).

Together, these results indicate that type III NRG1 is an instructive signal; threshold levels trigger Schwann cell myelination, and, above that threshold, the amount of compact myelin formed is graded to the levels of type III NRG1. As NRG type III also controls Schwann cell proliferation and survival, elevated levels of NRG1 type III drive generation of the additional Schwann cells required for myelination, thereby coordinating Schwann cell numbers to their myelinating fate (Taveggia et al. 2005).

Once myelination is complete, ongoing signaling from axonal NRG1 or erbB receptors is not required to maintain the myelin sheath (Atanasoski et al. 2006; Fricker et al. 2011). This notion agrees with the rare "double" myelin sheaths found in the sympathetic trunk in which the outer myelin sheath is displaced from contact with the axon, but continues to be maintained (Heath et al. 1991). After injury, axonal NRG is surprisingly dispensable, al- 
J.L. Salzer

though it does promote timely remyelination (Fricker et al. 2013; Stassart et al. 2013). This reflects the up-regulation and secretion of a soluble NRG isoform by Schwann cells, which functions as an autocrine signal that is necessary and sufficient to promote remyelination (Stassart et al. 2013). These findings raise the possibility that administration of soluble NRG1 may enhance repair in some settings.

All NRG1 isoforms, including type III, are cleaved by metalloproteinases just extracellular to the plasma membrane (Falls 2003). This cleavage releases the ectodomain from the type I and II isoforms, which then function as paracrine signals. In contrast, the type III isoform has a second, amino-terminal hydrophobic sequence and is, therefore, retained on the axon membrane after cleavage, functioning as a juxtacrine signal (Falls 2003; Taveggia et al. 2005). A variety of metalloproteinases have been implicated in NRG1 cleavage (Shirakabe et al. 2001; Horiuchi et al. 2005; Luo et al. 2011b), including BACE and TACE (also called ADAM17). Cleavage by these proteases has opposing functional effects. BACE cleavage activates NRG1 and is required for normal myelination; mice deficient in this enzyme are hypomyelinated in both the PNS and CNS (Hu et al. 2006; Willem et al. 2006). In contrast, TACE cleavage inactivates NRG1, and mice with conditional loss of TACE are hypermyelinated (La Marca et al. 2011). Dual cleavage by both TACE and BACE may release the type III ectodomain, allowing it to function as a paracrine signal (Fleck et al. 2013). Although NRG1 is the likely substrate that accounts for these protease effects on myelination, it is also possible that other protein substrates at the membrane surface (Hogl et al. 2013) may also be involved. Together, these results suggest that competition between secretases may regulate the extent of myelination. Thus, modulating NRG1 cleavage with secretase inhibitors may be a useful strategy for the therapy of de-/dysmyelinating disorders.

\section{Lgi4 and Adam22}

Adam 22 has recently emerged as a second, key axonal signal that promotes myelination. Ap- preciation of its role in myelination resulted from investigations of the spontaneous, recessive mutation claw paw (clp), which results in PNS-specific hypomyelination (Henry et al. 1991). Positional cloning showed that $c l p$ arises from an insertion in the Lgi4 gene, leading to a mutant Lgi4 protein that lacks exon 4 (Bermingham et al. 2006). Subsequent studies showed that Lgi4 is secreted by Schwann cells and binds in a paracrine fashion to Adam 22 axons. These interactions are necessary for Schwann cells to advance beyond the promyelinating stage (Kegel et al. 2013). Panknockouts of Adam22 (Sagane et al. 2005), Schwann cell-specific deletion of Lgi4, or neuron-specific deletion of Adam 22 (Ozkaynak et al. 2010) all result in major defects of myelination. The mechanism(s) by which Lgi4-Adam22 interactions promote myelination is a key, unresolved question, including whether binding of Lgi4 to Adam 22 on the axon converts this axonal protein to a promyelinating signal (by modifying its confirmation or association with other axonal proteins) or affects other axonal proteins that interact with the Schwann cell. Interestingly, Lgi4-Adam22 interactions have distinct roles at other stages of the lineage. Thus, Lgi4 is required for the proliferation of glial-restricted progenitors, but not Schwann cells (Nishino et al. 2010), and, in the mature myelinated fiber, it functions as part of the juxtaparanodal complex (Ogawa et al. 2010).

\section{The Basal Lamina: Laminin and Laminin Receptors}

Extracellular matrix components, including laminin, are synthesized by the Schwann cell and function as critical autocrine signals essential for ensheathment and myelination (Bunge et al. 1986; Chernousov et al. 2008). Evidence for the key role of laminin was initially suggested by the phenotype of dystrophic mice, which assemble a defective basal lamina and have amyelinated spinal roots (Madrid et al. 1975). Subsequently, Schwann cells were shown to be unable to myelinate axons in cocultures in the absence of basal lamina assembly; addition of laminin to such cultures rescued myelination, providing compelling support for its role (Bunge et al. 
1986). Finally, conditional knockout of laminin in Schwann cells results in aberrant ensheathment and myelination in vivo (Chen and Strickland 2003), effects that depend on a critical threshold level of laminin (McKee et al. 2012). Other components of the matrix, notably the collagens, also regulate Schwann cell myelination (Chernousov et al. 2008).

Laminin itself is a trimer comprised of different $\alpha, \beta$, and $\gamma$ chains. Laminin $2(\alpha 2 \beta 1 \gamma 1)$ is the principal endoneurial form; laminin 411 and laminin 511 are minor forms (Chernousov et al. 2008). Laminin 2, as well as the minor isoforms, promote radial sorting and myelination (Wallquist et al. 2005; Yang et al. 2005). Several different laminin receptors expressed on the abaxonal membrane, including $\beta 1$ integrins and dystroglycan, transduce the effects of laminin. Laminin promotes Schwann cell ensheathment and myelination via several cooperative mechanisms. These include establishing Schwann cell polarity (Bunge et al. 1986) akin to its role in many cell types (Li et al. 2003), activation of Schwann cell signaling pathways, and organizing the abaxonal membrane, including the Cajal bands (Court et al. 2011b). Finally, the basal lamina may provide structural support that anchors the abaxonal membrane and prevents the Schwann cell from migrating around the axon during myelination (Bunge et al. 1989).

Laminin regulates a wide array of signaling pathways to promote axon sorting, including members of the Rho family of GTPases, notably Rac1. Other downstream effectors implicated in radial sorting events include focal adhesion kinase (FAK), which is present in the abaxonal compartment (Fernandez-Valle et al. 1998) and drives expansion of the Schwann cell pool essential for radial sorting (Grove et al. 2007). Integrin-linked kinase (ILK) also promotes radial sorting and remyelination via an inhibition of Rho kinase (ROCK), thereby enhancing assembly of the actin cytoskeleton (see below) (Pereira et al. 2009; Montani et al. 2014). Recent studies also implicate the Jun activation domain-binding protein 1 (Jab1) as an effector of laminin signaling via a novel mechanism involving control of Schwann cell cycle and differentiation (Porrello et al. 2014).

\section{Gpr126}

The Schwann cell adhesion G-protein-coupled receptor (aGPCR), Gpr126 plays a key role during Schwann cell development by enhancing radial sorting (Mogha et al. 2013). Gpr126 is absolutely required for myelination (Monk et al. 2009). Recent studies strongly suggest that Gpr126 is the long-sought receptor that regulates Schwann cell cAMP levels, an essential signal for Schwann cell myelination (Glenn and Talbot 2013b). Gpr126, which is coupled to both $G_{s}$ and $G_{i}$, can directly elevate cAMP levels (Mogha et al. 2013) and activate PKA (Glenn and Talbot 2013a). In agreement, Gpr126 null Schwann cells are still able to myelinate axons if cAMP levels are elevated or PKA is activated (Glenn and Talbot 2013a; Mogha et al. 2013). The ligand for Gpr126 has not yet been identified and could be either expressed by the axon and/or in the matrix. The latter possibility is suggested by recent evidence that Gpr56, another aGPCR, is activated by binding to collagen III (Luo et al. 2011a; Glenn and Talbot 2013b).

Interestingly, once myelination is initiated, Gpr126 and elevation of cAMP levels are no longer required for ongoing myelination or, like NRGI, for myelin maintenance (Glenn and Talbot 2013a,b). These latter results contrast with the requirement for ongoing expression of the TFs, Krox20 and Sox10, to maintain myelin. Together, these results indicate that, once myelination is established, ongoing TF expression becomes cell autonomous, presumably, via a feedforward cascade, which does not depend on extrinsic signals.

\section{INTRACELLULAR SIGNALING PATHWAYS THAT REGULATE MYELINATION}

Significant effort, and progress, has focused on delineating the promyelinating signaling pathways downstream from these extrinsic signals that drive transcription, membrane biogenesis, and axon wrapping. Given its key role in myelination, substantial attention has focused on how NRG1 mediates its effects. Binding of NRG1 to the $\operatorname{erbB2} / 3$ heterodimer activates a 
series of canonical intracellular pathways downstream from many receptor tyrosine kinases (RTKs), that is, PI3K, PLC- $\gamma$, and mitogenactivated protein kinase (MAPK) (Lemmon and Schlessinger 2010). Each of these pathways have been compellingly implicated in Schwann cell development and differentiation downstream of NRG1 (Newbern and Birchmeier 2010); their precise role(s) in promoting Schwann cell differentiation and myelination are still emerging.

PI3K/Akt/mammalian target of rapamycin ( $m$ TOR). The PI3K pathway plays a key role in Schwann cell development (i.e., proliferation, survival, and the initiation of myelination), based on pharmacological inhibition and overexpression studies (Maurel and Salzer 2000; Ogata et al. 2006). Recent gain-of-function studies extend these findings. Thus, activation of the PI3K pathway by conditional deletion of PTEN, a lipid phosphatase with opposing effects, results in enhanced Schwann cell wrapping, even around collagen fibers, and hypermyelination of axons (Goebbels et al. 2010). Many of the effects of hyperactivation of PI3K in Schwann cells appear to be caused by activation of the serine/threonine kinase Akt, and its activation of mTOR. Thus, treatment of mice with activated PI3K pathway with rapamycin reverses many of these hyperwrapping effects (Goebbels et al. 2012; E Domenech, H Baloui, and JL Salzer, in prep.). Conditional inactivation of mTOR in embryonic Schwann cells results in thin, short myelin sheaths, providing direct evidence for its key role in PNS myelination (Sherman et al. 2012a). mTOR activation is strongly driven by NRG and, accordingly, is initially localized along sites that contact the axon (Heller et al. 2014). These latter results suggest that the hypomyelination observed in mice haploinsufficient for NRG1 (Michailov et al. 2004; Taveggia et al. 2005) is, in part, a result of reduced mTOR activity. The precise role(s) of mTOR during myelination are yet to be established, but seem likely to reflect its key role in regulating protein translation (Laplante and Sabatini 2013), including, potentially, of proteins required for myelination. Ongoing studies should also clarify whether mTOR mediates its effects via the
TORC1 complex as it does in CNS myelination (Bercury et al. 2014).

PLC- $\gamma$. The PLC- $\gamma$ pathway has also been implicated as an important mediator of NRG1 effects (Kao et al. 2009). Binding of NRG to erbB coreceptors activates PLC- $\gamma$, resulting in elevated intracellular calcium and activation of the phosphatase calcineurin B, which, in turn, results in dephosphorylation of cytosolic nuclear factor of activated $\mathrm{T}$ cells (NFAT) proteins; these, then, accumulate in the nucleus and induce NFAT-mediated gene transcription (Kao et al. 2009). NFATc4 binds cooperatively with Sox10 to the MSE of Krox20 (Kao et al. 2009; Lazarevic et al. 2009); it also binds directly to the P0 promoter to drive P0 transcription. These studies also suggest that NFAT is expressed early in the Schwann cell lineage and promotes axon sorting/ensheathment, in addition to its later effects on myelin gene transcription (Kao et al. 2009).

$M A P K$. Recent loss- and gain-of-function studies in mouse models show that the MAPK pathway is critical for promoting early Schwann cell differentiation and is a key signal that mediates the promyelinating effects of NRG1. Thus, Shp2, a phosphatase that activates MAPK, is required for normal Schwann cell differentiation and myelination; conditional inactivation of Shp2 phenocopies that of the erbB2 knockout (Grossmann et al. 2009). Likewise, conditional ablation of Gab1, a scaffolding protein required for RTK signaling, results in reduced Erk activation and substantial hypomyelination (Shin et al. 2014). Direct evidence for the role of the MAPK pathway was shown by combined, genetic ablation of Erk1/2 during development, which results in impaired Schwann cell differentiation and myelination (Newbern et al. 2011). Finally, in a recent study (Sheean et al. 2014), conditional expression of an "activated" form of MAPK (Mek1) in Schwann cells results in a sustained increase in the amount of myelination. Of note, transgenic expression of this activated Mek1 in Schwann cells deficient in erbB3 or Shp2, rescues Schwann cell proliferation, migration, and myelination of axons (Sheean et al. 2014).

These results compellingly implicate MAPK as a crucial signaling pathway downstream from 
Nrg1 in promoting Schwann cell myelination. MAPK activates the promyelinating TF YY1 (He et al. 2010). However, the promyelinating effects of MAPK activation may depend substantially on its stimulation of mTOR-dependent and -independent protein translation, which normally subsides at the onset of myelination. The ability of this single pathway to rescue myelination was unexpected, given the absence of NRG1-dependent activation of PI3K and PLC- $\gamma$. It suggests that either MAPK can indirectly activate these pathways or that other extrinsic signals activate these pathways at sufficient levels for myelination to ensue even in the absence of erbB3 signaling.

$c A M P$. This intracellular signal is known to promote and maintain the myelinating phenotype of Schwann cells (Stewart et al. 1991; Monje et al. 2010). It appears to do so via a number of mechanisms. cAMP converts the response of Schwann cells to NRG1 from proliferation to differentiation (Arthur-Farraj et al. 2011). It increases the expression of the promyelinating TF, Pou3f1 (Monuki et al. 1989), and in cultured cells was shown to cooperate with NFAT to drive Krox20 expression (Kipanyula et al. 2013). cAMP activates cAMP-dependent PKA, which promotes Schwann cell myelination in cocultures (Howe and McCarthy 2000) and Gpr126deficient zebrafish (Glenn and Talbot 2013a). PKA phosphorylates and activates several TFs. Among these are NF-кB and members of the CREB family including CREB1, CREM, and ATF1, which bind as dimers to cAMP-responsive elements (CREs) (Tasken and Aandahl 2004). Studies in myelinating cocultures suggest that induction of Schwann cell differentiation by cAMP and NRG1 require the activity of CREB family members (Arthur-Farraj et al. 2011). Future studies that directly target the activity of CREB TFs in vivo will establish their role more precisely in myelination.

\section{Termination of Myelination}

The tight correlation of myelin sheath thickness to axon diameter suggests that there are controls that limit myelin thickness. A key question is what terminates myelination? Some mecha- nisms have recently begun to emerge. In particular, as development proceeds, promyelinating signaling components of the NRG1/ erbB signaling pathway are down-regulated and, conversely, negative regulators, which function as "brakes" on signaling, are up-regulated. NRG1 activity is itself subject to negative regulation, in part, via a neuron-autonomous effect of vimentin (Triolo et al. 2012). NRG1 activity is also downregulated as a consequence of TACE cleavage (La Marca et al. 2011). In addition, Schwann cell expression of erbB2 (Cohen et al. 1992; Jin et al. 1993) and Akt (Heller et al. 2014; Sheean et al. 2014) are markedly down-regulated with myelination. Elucidating whether other promyelinating signals are similarly down-regulated will be of future interest.

Negative regulation of the PI3K/Akt/ mTOR pathway also limits the extent of myelination. PTEN is recruited to the adaxonal compartment by interactions with Dlg1, resulting in down-regulation of (NRG1-dependent) PI3K activation. However, loss of Dlg1 results in only a modest, transient hypermyelination (Cotter et al. 2010), indicating other mechanisms also exist. Among these are REDD1, which inhibits mTOR activity. Loss of REDD1 results in enhanced TORC1 activation and modest, sustained hypermyelination (Noseda et al. 2013).

Unexpectedly, the basal lamina, which is required for initial differentiation and radial sorting by Schwann cells, also limits the amount of myelin that forms. Such an inhibitory role was suggested by older studies of the $\alpha 2$ and $\alpha 4$ laminin chain knockouts. Although the most striking defects in these knockout mice was a failure of radial sorting and myelin initiation, nerves also displayed examples of hypermyelinated fibers and polyaxonal myelination, respectively (Bradley and Jenkison 1973; Wallquist et al. 2005). Hypermyelination of axons and polyaxonal myelination have also been observed in human dystrophic nerves (Di Muzio et al. 2003) and mice with conditional ablation of dystroglycan (Saito et al. 2003) or periaxin (Gillespie et al. 2000). Recent studies also show that laminin $-\alpha 6 \beta 4$ interactions in the abaxonal compartment activate Sgk1, which transiently inhibits myelination (Heller et al. 2014). More 
J.L. Salzer

sustained hypermyelination is observed in mice lacking collagen VI in the basal lamina, accompanied by a significant reduction in $g$ ratios (Chen et al. 2014). Interestingly, there are significant increases in the levels of FAK, Akt, and Erk signaling in the nerves from these mice (Chen et al. 2014). The mechanism(s) by which collagen VI down-regulates these signaling pathways is not known, but has important therapeutic implications.

\section{Activation of Signaling Pathways Can Also Drive Dedifferentiation}

A current paradox is that high-level activation of signaling pathways that promote myelination can, under some circumstances, inhibit myelination and even result in frank demyelination. This was originally shown in myelinating cocultures in which addition of type II NRG1, but not other NRG1 isoforms, results in substantial demyelination (Zanazzi et al. 2001). Demyelination was also observed in vivo in transgenic overexpressors of this NRG isoform (Huijbregts et al. 2003). Subsequently, studies suggested that this dedifferentiation is attributable to activation of the MAPK and Jun kinase pathways, and this activation may function to reprogram the Schwann cell during the injury response (Parkinson et al. 2008; Napoli et al. 2012). Indeed, an emerging number of growth factors and signaling pathways that negatively regulate myelination, including the Notch pathway (Woodhoo et al. 2009), have been identified. The normal role of these negative regulators may be in fine-tuning the onset of myelination during development and promoting the regenerative phenotype of the Schwann cells following injury, as discussed in Jessen et al. (2015). Such dedifferentiative pathways may also contribute to demyelination in pathological settings and, as such, offer the potential for the development of rational therapeutic approaches to demyelinating neuropathies.

\section{THE MORPHOGENESIS OF THE MYELIN SHEATH}

Early electron microscopic studies established the myelin sheath forms as the result of spiral wrapping of the Schwann cell plasma membrane around the axon (Geren 1954). The myelin sheath is initially loosely spiraled for the first few turns, then compacts with up-regulation of myelin proteins, notably P0 (Kidd et al. 2013). In a classic study, Bunge et al. (1989) provided compelling evidence that spiral wrapping results from circumnavigation of an inner turn around the axon rather than by migration of the Schwann cell soma/nucleus in the outer compartment around the sheath. This model was also suggested by earlier studies in which developing nerves in tadpole tails were live imaged (Speidel 1964).

The innermost turns are likely to be initially narrower than the full expanse of the internode, as suggested by older electron microscopy (EM) studies (Webster 1971), and expand laterally as the sheath matures. This interpretation is strongly supported by staining for the paranodal marker Caspr, which delineates the lateral edge of the Schwann cell. At the onset of myelination, Caspr is initially concentrated in a loose spiral that extends into the internode; this spiral progressively concentrates into a tight band as myelin matures (Pedraza et al. 2001). Compelling, direct support for this model was provided by live imaging and quantitative morphometry of the developing, CNS myelin sheath (Snaidero et al. 2014; Simons and Nave 2015).

Thus, expansion of the myelin sheath is likely to occur along the inner turn and at the lateral margins of the sheath, which function as the equivalent of leading edges of the expanding sheath (Kidd et al. 2013). Growth of the inner membrane requires it to intercalate between the existing inner membrane and the axon (see Fig. 5), disrupting existing interactions between the axon and Schwann cell. Whether expansion of the inner turn is guided by interactions with the axon (heterotypic interactions), the glial membrane (homotypic interactions), or both is not yet known. New components of the membrane are added in the abaxonal and perinuclear region (Gould 1977) and, potentially, within the paranodes (Gould and Mattingly 1990); these components then diffuse throughout the forming myelin sheath. This occurs much more rapidly for membrane lipids than myelin proteins 
(Gould 1977). Interestingly, even after compact myelin has formed, the sheath rapidly expands and its internal circumference continues to increase to accommodate radial expansion of the axon (Webster 1971). Together, these results suggest that the myelin sheath conforms to the classical model of a fluid mosaic membrane, with diffusion potentially enhanced by its high-lipid content.

A related question is what determines the length of the myelin internode during development? Together with axon diameter and myelin thickness, internode length is a key determinant of nerve conduction velocity (Waxman 1980). Much of the expansion of the internode during development is thought to result from axon elongation dictated by growth of the developing limbs (Hildebrand et al. 1994). Experimental manipulations that gradually elongate limbs result in increased internode length (Abe et al. 2004; Simpson et al. 2013), whereas impairment of limb development reduces internode length (Hildebrand et al. 1989). There is some modification of internode length that results from alterations in the numbers of Schwann cells available for myelination, with a reduction or an increase in Schwann cells resulting in an increase or decrease of internode length, respectively (Hildebrand et al. 1994). In the normal, adult peripheral nerve, internode lengths are optimized for their role in saltatory conduction (Simpson et al. 2013). Conversely, the short internodes, characteristic of remyelinated segments (Scherer and Salzer 2000), likely contribute to reduced nerve conduction velocities. Such short, remyelinated segments are thought to result from myelin formation around adult axons that are no longer actively elongating.

Finally, formation of the myelin sheath requires dramatic expansion of the plasma membrane. By some estimates, myelinating Schwann cells may generate up to $20 \mathrm{~mm}^{2}$ of membrane around the largest axons-some 2000 times that of a typical epithelial cell (Kidd et al. 2013). The rapid membrane production that occurs during myelination requires coordination of gene transcription, protein translation, directed trafficking of myelin components to sites of membrane addition, and mechanisms that establish the proper stoichiometry of these myelin components. Indeed, alterations in the stoichiometry of myelin proteins, such as PMP22 and P0 resulting from haploinsufficiency or overexpression, result in genetic neuropathies (Suter and Scherer 2003). Production of this huge expanse of membrane imposes significant stresses on the Schwann cell, including in the ER, rendering them especially vulnerable to proteins that fold or traffic aberrantly. This is evident in the pathology of many inherited neuropathies (D’Antonio et al. 2009, 2013).

\section{RADIAL SORTING AND MYELINATION: ROLE OF THE ACTIN CYTOSKELETON}

A long-standing question is what drives the circumferential expansion of the Schwann cell membrane that propels radial sorting and myelination? In motile cells, branched and crosslinked networks of actin provide the major engine for movement of the lamellipodial membrane by polymerizing against it (Blanchoin et al. 2014). Likewise, radial sorting, wrapping, and elongation of the Schwann cell along the axon rely on the precise spatial and temporal remodeling of the actin cytoskeleton along the lateral and inner membrane. F-actin is present in essentially all cytoplasmic compartments of myelinating Schwann cells, that is, the SchmidtLanterman incisures, the periaxonal membrane, the paranodes, and the outer and inner mesaxon and paranodal loops (Trapp et al. 1989)—sites of morphogenesis during myelination. Inhibition of actin assembly blocks myelination in coculture models (Fernandez-Valle et al. 1997). Interestingly, the effects of inhibiting actin assembly are dose dependent with high doses blocking all ensheathment and intermediate doses permitting axon segregation, but not myelin progression (Fernandez-Valle et al. 1997). Similarly, inhibition of myosin II in cocultures blocks axon sorting and myelination (Wang et al. 2008). Unexpectedly, inhibition of myosin II appears to potentiate CNS myelination, indicating that myelination in the PNS and CNS is mechanistically distinct (Wang et al. 2008).

Consistent with the key role of the actin/ myosin cytoskeleton in myelin morphogenesis, 
an increasing number of regulators of actin assembly have been implicated in Schwann cell myelination (Fig. 5). Among these are Rho, Rac1, and cdc42, foundational members of the small Rho GTPase family of proteins. Rho family members are master regulators of cytoskeleton dynamics that control a wide array of morphogenetic events; they function as molecular switches, cycling between inactive guanosine diphosphate (GDP)-bound and active guanosine triphosphate (GTP)-bound states (Heasman and Ridley 2008; Hall 2012). Conditional inactivation of Rac1 or cdc42 during Schwann cell development results in impaired axon sorting, delayed myelination, and significant hypomyelination (Benninger et al. 2007; Nodari et al. 2007). Loss of cdc42 also impairs Schwann cell proliferation (Benninger et al. 2007) and the function of the Par3 polarity complex (Goldstein and Macara 2007), both of which are likely to affect radial sorting. Interestingly, conditional knockouts of Racl and cdc42 have distinct and less-severe effects on oligodendrocyte myelination (Thurnherr et al. 2006), further underscoring differences between PNS and CNS myelination. Rho and its key effector ROCK promote radial sorting (Pereira et al. 2009) and the coordinated progression of the inner turn of the myelin sheath around the axon at the onset of myelination via regulation of actomyosin assembly (Melendez-Vasquez et al. 2004).

Multiple extrinsic signals have been implicated in activating these various GTPases. cdc42 is activated in cultured Schwann cells by soluble NRG1 (Benninger et al. 2007); the importance of NRG1 as an activator of cdc42 in vivo is not yet established. In contrast, Racl is activated downstream from laminin $/ \beta 1$ integrin signaling (Benninger et al. 2007; Nodari et al. 2007). Indeed, overexpression of Rac1 partially rescues the phenotype of Schwann cell conditional $\beta 1$ integrin nulls (Nodari et al. 2007). Activation of Racl downstream from integrins involves the lymphoid cell kinase (Lck) in a pathway that also includes paxillin and CrkII (Ness et al. 2013).

The pathways downstream from these GTPases, and how they regulate the cytoskeleton, are complex and incompletely understood.
One key effector is the neuronal Wiskott-Aldrich syndrome protein (N-WASP), which is downstream from Rac1 and cdc42; it is known to bind to the Arp2/3 complex to nucleate new branched arrays of actin filaments (Burianek and Soderling 2013). N-WASP localizes to the leading edge of Schwann cell processes (Bacon et al. 2007); its expression peaks early postnatally (Jin et al. 2011). Pharmacological inhibition of N-WASP in Schwann cell cultures prevents activation of the Arp2/3 complex and impairs myelination in cocultures (Bacon et al. 2007). Conditional inactivation of N-WASP markedly delays sorting and profoundly impairs myelin wrapping (Jin et al. 2011; Novak et al. 2011); the few cells that myelinate have markedly shorter internodes, indicating that elongation and spiral membrane wrapping share similar actin machinery. Interestingly, Schwann cells are still able to initiate the transcriptional program of myelination in mutants, indicating that myelin morphogenesis and transcriptional activation are not obligately linked. N-WASP is an effector of cdc42 (Rohatgi et al. 1999) and, thus, potentially links NRG1-dependent activation of cdc42 to actin assembly at the leading edge of the myelinating Schwann cell. Arguing against this model, however, maximal N-WASP expression is present in the abaxonal compartment (Jin et al. 2011). Other studies suggest that cdc42 may also promote radial sorting, in part, via NF2/merlin (Guo et al. 2013). Finally, recent studies suggest that the Rho/ROCK pathway promotes lamellipodia by a separate, parallel pathway involving myosin light-chain kinase (MLCK) and activation of myosin II and by activating the actin-binding protein profilin1; this latter pathway is negatively regulated by ILK (Montani et al. 2014).

In addition to proteins that promote its assembly and branching, depolymerization of the actin cytoskeleton is also actively regulated, including by the actin-severing protein cofilin. NRG1 activates cofilin via the cofilin-phosphatase Slingshot1, which is activated by translocation to and association with F-actin at the leading edge of lamellipodia (Nagata-Ohashi et al. 2004). In agreement, NRG1 promotes translocation of nonphosphorylated cofilin to 
the leading edge of cultured Schwann cells (Sparrow et al. 2012). Further, knockdown of cofilin1 in cultured synaptonemal complexes (SCs) blocked their engagement or alignment along axons, assembly of the basal lamina, and ability to myelinate (Sparrow et al. 2012).

Taken together, these findings suggest that actin is dynamically and obligately regulated during axon segregation and myelination. Based on ligand activation and localization studies, NRG1/erbB activate cofilin and cdc42 at the leading edge of the adaxonal membrane, leading to a cycle of actin depolymerization and N-WASP-dependent assembly, respectively; these results are consistent with actin treadmilling known to underlie lamellipodial extension in most cells (Pollard and Borisy 2003). In addition, Racl and Rho/ROCK act in the abaxonal compartment downstream from laminin/ $\beta 1$ integrin to drive actinomyosin activity required for radial sorting. Future studies to further delineate the spatial and temporal regulation of these diverse actin regulatory pathways, and identify additional effectors, will provide important insights into both myelin formation and, potentially, prospective remodeling of PNS myelin sheaths in the adult and following injury.

\section{FUNCTIONAL CONSEQUENCES OF MYELINATION ON THE AXON}

Myelinating Schwann cells profoundly reorganize the underlying axon, including its domain organization, the axonal cytoskeleton, and its metabolic requirements. As a consequence, the axon is especially vulnerable to loss of myelin, which significantly contributes to the morbidity of dysmyelinating and demyelinating disorders. The role of myelin on the domain organization of axons is considered in detail elsewhere in the literature (Rasband and Peles 2015). Here, we briefly highlight other effects of myelination on the axon.

Local Regulation of the Axonal Cytoskeleton and Transport

Myelinating Schwann cells promote the radial expansion of the underlying axon (Aguayo et al.
1979; Windebank et al. 1985; Waegh et al. 1992), which, in turn, increases nerve conduction velocity (Gasser and Grundfest 1939). Radial expansion is locally regulated and most evident along the internode of large PNS fibers. Thus, the diameter of the axon in the paranodal and nodal regions may be as little as $15 \%-20 \%$ of that of the internode (Berthold 1996). Interestingly, the reduced diameter of the axon at the node and paranodes may also enhance conduction velocity by reducing the surface area and, thereby, the capacitance of the nodal axolemma (Halter and Clark 1993).

The signals from myelin, which drive radial expansion, remain incompletely understood. Their highly local nature is apparent in the reduced diameter of the axon present immediately underneath regions of noncompact myelin (e.g., Schmidt-Lanterman incisures) (Price et al. 1993). One mechanism involves MAG, which is required for full phosphorylation of neurofilament subunits (Yin et al. 1998) and thereby regulates the packing of the neurofilament cytoskeleton (Waegh et al. 1992; Cole et al. 1994). Regions of greatest expansion are associated with more substantial neurofilament phosphorylation and a lower density of neurofilaments/square area (Price et al. 1993).

It has also long been known that myelination regulates axonal transport. The rates of slow and fast axonal transport are reduced in the nodal and paranodal regions (Waegh et al. 1992; Zimmermann 1996; Salzer 2003). This is evident by the accumulation of $>90 \%$ of the membranous organelles in the nodes and paranodes of large, myelinated axons (Berthold et al. 1993). Direct support for a reduction in transport rates was provided by live imaging (Cooper and Smith 1974) and accumulation of metabolically labeled glycoproteins at this site (Armstrong et al. 1987). The mechanism(s) responsible for the reduction of transport in the nodal/paranodal region are not known, but may result from the constricted axon diameter at this site (Zimmermann 1996) or potentially alterations of microtubule-motor interactions. EM tomography suggests that the paranodes may directly regulate vesicle transport (Nans et al. 2011). The accumulation of mitochondria and vesicles in 
(Caspr) knockout mice (Einheber et al. 2006; Garcia-Fresco et al. 2006) also support a role for the paranodes in regulating transport.

\section{Metabolic Support and Transfer of Macromolecules}

Peripheral nerves can be 100 feet or more in length in the blue whale and may have been as long as 200 feet in the largest of the sauropods, based on fossil records (Wedel 2011). This enormous expanse of axon underscores the need for and, likely, ancestral role of (myelinating) Schwann cells, that of the trophic support of long axons (Nave 2010).

Schwann cells have long been known to provide trophic support for axons (Varon and Bunge 1978). This requirement is strikingly evident in the developmental loss of PNS neurons/axons in mutant mice that lack Schwann cells (Birchmeier 2009). The focus of current studies of how myelinating glia maintain axons has shifted from growth factors, for example, neurotrophic factors, to metabolism. The axon is largely shielded from the extracellular space along its entire length by the overlying myelin sheath, except at the nodes of Ranvier. This suggests that myelinating glia release metabolites that are transported into and sustain the metabolism of axons in both the CNS and PNS. This has been recently shown in the case of oligodendrocytes, which provide lactate as a source of energy to axons and thereby prevents axonal degeneration (Funfschilling et al. 2012; Lee et al. 2012). Similarly, disruption of mitochondrial function in Schwann cells has, as its major pathological feature, the progressive degeneration of small fiber and myelinated axons (Viader et al. 2011). In the latter case, this is a result of a shift in Schwann cell lipid oxidation that culminates in release of toxic acylcarnitines with resultant axonal degeneration (Viader et al. 2013). Together, these findings have important implications for the axonal loss observed in myelin disorders.

Recent studies have also revived interest in the provocative notion that macromolecules, notable RNA and ribosomes, are transferred from the Schwann cell to the axon. This possibility was suggested in older studies analyzing the squid giant axon (Lasek et al. 1977; Cutillo et al. 1983) and has been supported by newer, genetic labeling strategies, which are coupled to analysis of transected axons to eliminate the soma as a source of components. These recent studies suggest that messenger RNA (mRNA) (Sotelo et al. 2013) and ribosomes (Court et al. 2008) are transferred from the Schwann cell to the axon during injury (Twiss and Fainzilber 2009) and regeneration (Court et al. 2011a). Transfer from the Schwann cell to the axon appears to be concentrated at the incisures and in the nodal region and requires actin and myosin (Va) (Sotelo et al. 2013). Future studies that address the functional significance of this transfer and the extent to which transfer also occurs during nerve development and/or in the uninjured adult PNS will be of considerable interest.

\section{CONCLUSIONS}

There has been gratifying progress in our understanding of Schwann cell myelination, including identification of key extrinsic signals, the intracellular pathways they activate, and the transcriptional and epigenetic programs that cooperate to promote the myelinating phenotype. Important questions remain. Among these is how the transcriptional program is coupled to the morphogenesis of the myelin sheath? Frequently, an arrest in myelination caused by transcription is associated with an arrest of myelin wrapping, particularly, at the promyelinating stage. This suggests that these processes are coupled by an as-yet unknown mechanism to ensure that membrane expansion is coordinated to wrapping; local translational control may also be involved.

With the identification of multiple extrinsic regulators of Schwann cell myelination, a challenge is to delineate the spatiotemporal activity of their downstream signaling pathways and effectors, determine the effects of combinatorial signaling, and elucidate further the mechanisms that terminate their activity. Axonal and matrix signals activate pathways in the adaxonal 
and abaxonal compartments, respectively. How are these pathways integrated? In particular, how are the signals from both compartments coordinated to regulate the axonal cytoskeleton remodeling during myelination? The extent to which extrinsic signals terminate ongoing myelination and/or inhibit myelination of small fibers is also not well understood.

Finally, whether axonal activity regulates myelin formation by Schwann cells, their trophic (reciprocal) support of axons, and the plasticity and maintenance of myelin in the adult are important unanswered questions (Samara et al. 2013). Recent studies of CNS myelination indicate a surprising amount of ongoing myelination in the adult (Young et al. 2013) and suggest that neural activity and experience may be important regulators of oligodendrocyte myelination (Liu et al. 2012; Makinodan et al. 2012; Gibson et al. 2014). Schwann cells are known to express a variety of proteins that allow them to detect signals produced by electrically active axons (Samara et al. 2013). In the PNS, older coculture studies suggest that activity may indeed regulate Schwann cell myelination (Stevens et al. 1998; Stevens and Fields 2000). More recent in vivo analysis also suggests a role of activity in myelin maintenance (Canu et al. 2009). Direct analysis of whether there is ongoing myelin remodeling in the adult PNS, including live imaging with methods and genetic strategies to modulate activity during development in vivo, will be of considerable interest for future investigation.

\section{ACKNOWLEDGMENTS}

This review is dedicated to three esteemed colleagues and friends: Dr. Marie Filbin, Dr. David Colman, and Dr. Jack Griffin. Their studies greatly contributed to our understanding of myelin biology; their bonhomie and enthusiasm fostered today's community of glial biologists. The author gratefully acknowledges his own laboratory colleagues, past and present, for their many contributions to studies cited here, Jill Gregory for outstanding artwork, and Bob Gould and John Svaren for helpful discussions. Studies from the author's laboratory have been supported by the National Institutes of Health and the National Multiple Sclerosis Society. The author regrets any omissions in citing relevant publications of other colleagues in the myelin field.

\section{REFERENCES}

${ }^{*}$ Reference is also in this collection

Abe I, Ochiai N, Ichimura H, Tsujino A, Sun J, Hara Y. 2004. Internodes can nearly double in length with gradual elongation of the adult rat sciatic nerve. J Orthop Res 22: $571-577$.

Aguayo AJ, Bray GM, Perkins SC. 1979. Axon-Schwann cell relationships in neuropathies of mutant mice. Ann NY Acad Sci 317: 512-531.

Armstrong R, Toews AD, Morell P. 1987. Axonal transport through nodes of Ranvier. Brain Res 412: 196-199.

Arthur-Farraj P, Wanek K, Hantke J, Davis CM, Jayakar A, Parkinson DB, Mirsky R, Jessen KR. 2011. Mouse Schwann cells need both NRG1 and cyclic AMP to myelinate. Glia 59: 720-733.

Atanasoski S, Scherer SS, Sirkowski E, Leone D, Garratt AN, Birchmeier C, Suter U. 2006. ErbB2 signaling in Schwann cells is mostly dispensable for maintenance of myelinated peripheral nerves and proliferation of adult Schwann cells after injury. J Neurosci 26: 2124-2131.

Bacon C, Lakics V, Machesky L, Rumsby M. 2007. N-WASP regulates extension of filopodia and processes by oligodendrocyte progenitors, oligodendrocytes, and Schwann cells-Implications for axon ensheathment at myelination. Glia 55: 844-858.

Balice-Gordon RJ, Bone LJ, Scherer SS. 1998. Functional gap junctions in the Schwann cell myelin sheath. J Cell Biol 142: $1095-1104$.

Beirowski B, Gustin J, Armour SM, Yamamoto H, Viader A, North BJ, Michan S, Baloh RH, Golden JP, Schmidt RE, et al. 2011. Sir-two-homolog 2 (Sirt2) modulates peripheral myelination through polarity protein Par-3/atypical protein kinase C (aPKC) signaling. Proc Natl Acad Sci 108: E952-E961.

Benninger Y, Thurnherr T, Pereira JA, Krause S, Wu X, Chrostek-Grashoff A, Herzog D, Nave K-A, Franklin RJ, Meijer D, et al. 2007. Essential and distinct roles for cdc42 and racl in the regulation of Schwann cell biology during peripheral nervous system development. J Cell Biol 177: 1051-1061.

Bercury KK, Dai J, Sachs HH, Ahrendsen JT, Wood TL, Macklin WB. 2014. Conditional ablation of raptor or rictor has differential impact on oligodendrocyte differentiation and CNS myelination. J Neurosci 34: 4466-4480.

Bermingham JR Jr, Shearin H, Pennington J, O’Moore J, Jaegle M, Driegen S, van Zon A, Darbas A, Ozkaynak E, Ryu EJ, et al. 2006. The claw paw mutation reveals a role for Lgi4 in peripheral nerve development. Nat Neurosci 9: $76-84$.

Berthold CH. 1996. Development of nodes of Ranvier in feline nerves: An ultrastructural presentation. Microsc Res Tech 34: 399-421. 
J.L. Salzer

Berthold CH, Fabricius C, Rydmark M, Andersen B. 1993. Axoplasmic organelles at nodes of Ranvier. I. Occurrence and distribution in large myelinated spinal root axons of the adult cat. J Neurocytol 22: 925-940.

Birchmeier C. 2009. ErbB receptors and the development of the nervous system. Exp Cell Res 315: 611-618.

Blanchoin L, Boujemaa-Paterski R, Sykes C, Plastino J. 2014. Actin dynamics, architecture, and mechanics in cell motility. Physiol Rev 94: 235-263.

Bradley WG, Jenkison M. 1973. Neural abnormalities in the dystrophic mouse. J Neurol Sci 25: 249-255.

Bremer J, O’Connor T, Tiberi C, Rehrauer H, Weis J, Aguzzi A. 2010. Ablation of Dicer from murine Schwann cells increases their proliferation while blocking myelination. PLOS ONE 5: e12450.

Bremer M, Frob F, Kichko T, Reeh P, Tamm ER, Suter U, Wegner M. 2011. Sox10 is required for Schwann-cell homeostasis and myelin maintenance in the adult peripheral nerve. Glia 59: 1022-1032.

Brinkmann BG, Agarwal A, Sereda MW, Garratt AN, Muller T, Wende H, Stassart RM, Nawaz S, Humml C, Velanac V, et al. 2008. Neuregulin-1/ErbB signaling serves distinct functions in myelination of the peripheral and central nervous system. Neuron 59: 581-595.

Bunge MB, Williams AK, Wood PM. 1982. NeuronSchwann cell interaction in basal lamina formation. Dev Biol 92: 449-460.

Bunge RP, Bunge MB, Eldridge CF. 1986. Linkage between axonal ensheathment and basal lamina production by Schwann cells. Annu Rev Neurosci 9: 305-328.

Bunge RP, Bunge MB, Bates M. 1989. Movements of the Schwann cell nucleus implicate progression of the inner (axon-related) Schwann cell process during myelination. J Cell Biol 109: 273-284.

Burianek LE, Soderling SH. 2013. Under lock and key: Spatiotemporal regulation of WASP family proteins coordinates separate dynamic cellular processes. Semin Cell Dev Biol 24: 258-266.

Camargo N, Smit AB, Verheijen MH. 2009. SREBPs: SREBP function in glia-neuron interactions. FEBS J 276: 628636.

Canu MH, Carnaud M, Picquet F, Goutebroze L. 2009. Activity-dependent regulation of myelin maintenance in the adult rat. Brain Res 1252: 45-51.

Chan JR, Jolicoeur C, Yamauchi J, Elliott J, Fawcett JP, Ng BK, Cayouette M. 2006. The polarity protein Par-3 directly interacts with p75NTR to regulate myelination. Science 314: 832-836.

Chen ZL, Strickland S. 2003. Laminin $\gamma 1$ is critical for Schwann cell differentiation, axon myelination, and regeneration in the peripheral nerve. J Cell Biol 163: 889899.

Chen P, Cescon M, Megighian A, Bonaldo P. 2014. Collagen VI regulates peripheral nerve myelination and function. FASEB J 28: 1145-1156.

Chernousov MA, Yu WM, Chen ZL, Carey DJ, Strickland S. 2008. Regulation of Schwann cell function by the extracellular matrix. Glia 56: 1498-1507.

Cohen JA, Yachnis AT, Arai M, Davis JG, Scherer SS. 1992. Expression of the neu proto-oncogene by Schwann cells during peripheral nerve development and Wallerian degeneration. J Neurosci Res 31: 622-634.

Cole JS, Messing A, Trojanowski JQ, Lee VM. 1994. Modulation of axon diameter and neurofilaments by hypomyelinating Schwann cells in transgenic mice. J Neurosci 14: 6956-6966.

Cooper PD, Smith RS. 1974. The movement of optically detectable organelles in myelinated axons of Xenopus laevis. J Physiol 242: 77-97.

Cotter L, Ozcelik M, Jacob C, Pereira JA, Locher V, Baumann R, Relvas JB, Suter U, Tricaud N. 2010. Dlg1-PTEN interaction regulates myelin thickness to prevent damaging peripheral nerve overmyelination. Science 328: 14151418.

Court FA, Sherman DL, Pratt T, Garry EM, Ribchester RR, Cottrell DF, Fleetwood-Walker SM, Brophy PJ. 2004. Restricted growth of Schwann cells lacking Cajal bands slows conduction in myelinated nerves. Nature 431: 191-195.

Court FA, Hendriks WT, MacGillavry HD, Alvarez J, van Minnen J. 2008. Schwann cell to axon transfer of ribosomes: Toward a novel understanding of the role of glia in the nervous system. J Neurosci 28: 11024-11029.

Court FA, Midha R, Cisterna BA, Grochmal J, Shakhbazau A, Hendriks WT, Van Minnen J. 2011a. Morphological evidence for a transport of ribosomes from Schwann cells to regenerating axons. Glia 59: 1529-1539.

Court FA, Zambroni D, Pavoni E, Colombelli C, Baragli C, Figlia G, Sorokin L, Ching W, Salzer JL, Wrabetz L, et al. 2011b. MMP2-9 cleavage of dystroglycan alters the size and molecular composition of Schwann cell domains. J Neurosci 31: 12208-12217.

Cutillo V, Montagnese P, Gremo F, Casola L, Giuditta A. 1983. Origin of axoplasmic RNA in the squid giant fiber. Neurochem Res 8: 1621-1634.

D’Antonio M, Feltri ML, Wrabetz L. 2009. Myelin under stress. J Neurosci Res 87: 3241-3249.

D’Antonio M, Musner N, Scapin C, Ungaro D, Del Carro U, Ron D, Feltri ML, Wrabetz L. 2013. Resetting translational homeostasis restores myelination in Charcot-MarieTooth disease type 1B mice. J Exp Med 210: 821-838.

Decker L, Desmarquet-Trin-Dinh C, Taillebourg E, Ghislain J, Vallat JM, Charnay P. 2006. Peripheral myelin maintenance is a dynamic process requiring constant Krox20 expression. J Neurosci 26: 9771-9779.

Di Muzio A, De Angelis MV, Di Fulvio P, Ratti A, Pizzuti A, Stuppia L, Gambi D, Uncini A. 2003. Dysmyelinating sensory-motor neuropathy in merosin-deficient congenital muscular dystrophy. Muscle Nerve 27: 500-506.

Einheber S, Milner TA, Giancotti F, Salzer JL. 1993. Axonal regulation of Schwann cell integrin expression suggests a role for $\alpha 6 \beta 4$ in myelination. J Cell Biol 123: 1223-1236.

Einheber S, Bhat MA, Salzer JL. 2006. Disrupted axo-glial junctions result in accumulation of abnormal mitochondria at nodes of Ranvier. Neuron Glia Biol 2: 165-174.

Falls DL. 2003. Neuregulins: Functions, forms, and signaling strategies. Exp Cell Res 284: 14-30.

Fannon AM, Sherman DL, Ilyina-Gragerova G, Brophy PJ, Friedrich VL Jr, Colman DR. 1995. Novel E-cadherinmediated adhesion in peripheral nerve: Schwann cell ar- 
chitecture is stabilized by autotypic adherens junctions. J Cell Biol 129: 189-202.

Fernandez-Valle C, Gorman D, Gomez AM, Bunge MB. 1997. Actin plays a role in both changes in cell shape and gene-expression associated with Schwann cell myelination. J Neurosci 17: 241-250.

Fernandez-Valle C, Wood PM, Bunge MB. 1998. Localization of focal adhesion kinase in differentiating Schwann cell/neuron cultures. Microsc Res Tech 41: 416-430.

Filbin MT, Walsh FS, Trapp BD, Pizzey JA, Tennekoon GI. 1990. Role of myelin P0 protein as a homophilic adhesion molecule. Nature 344: 871-872.

Finzsch M, Schreiner S, Kichko T, Reeh P, Tamm ER, Bosl MR, Meijer D, Wegner M. 2010. Sox10 is required for Schwann cell identity and progression beyond the immature Schwann cell stage. J Cell Biol 189: 701-712.

Fleck D, van Bebber F, Colombo A, Galante C, Schwenk BM, Rabe L, Hampel H, Novak B, Kremmer E, Tahirovic S, et al. 2013. Dual cleavage of neuregulin 1 type III by BACE1 and ADAM17 liberates its EGF-like domain and allows paracrine signaling. J Neurosci 33: 7856-7869.

Fricker FR, Lago N, Balarajah S, Tsantoulas C, Tanna S, Zhu N, Fageiry SK, Jenkins M, Garratt AN, Birchmeier C, et al. 2011. Axonally derived neuregulin-1 is required for remyelination and regeneration after nerve injury in adulthood. J Neurosci 31: 3225-3233.

Fricker FR, Antunes-Martins A, Galino J, Paramsothy R, La Russa F, Perkins J, Goldberg R, Brelstaff J, Zhu N, McMahon SB, et al. 2013. Axonal neuregulin 1 is a rate limiting but not essential factor for nerve remyelination. Brain 136: $2279-2297$.

Friede RL. 1972. Control of myelin formation by axon caliber (with a model of the control mechanism). J Comp Neurol 144: 233-252.

Funfschilling U, Supplie LM, Mahad D, Boretius S, Saab AS, Edgar J, Brinkmann BG, Kassmann CM, Tzvetanova ID, Mobius W, et al. 2012. Glycolytic oligodendrocytes maintain myelin and long-term axonal integrity. Nature 485: 517-521.

Garcia-Fresco GP, Sousa AD, Pillai AM, Moy SS, Crawley JN, Tessarollo L, Dupree JL, Bhat MA. 2006. Disruption of axo-glial junctions causes cytoskeletal disorganization and degeneration of Purkinje neuron axons. Proc Natl Acad Sci 103: 5137-5142.

Garratt AN, Voiculescu O, Topilko P, Charnay P, Birchmeier C. 2000. A dual role of erbB2 in myelination and in expansion of the Schwann cell precursor pool. J Cell Biol 148: $1035-1046$

Gasser HS, Grundfest H. 1939. Axon diameters in relations to the spike dimensions and the conduction velocity in mammalian A fibers. Am J Physiol 127: 393-414.

Geren BB. 1954. The formation from the Schwann cell surface of myelin in the peripheral nerves of chick embryos. Exp Cell Res 7: 558-562.

Gibson EM, Purger D, Mount CW, Goldstein AK, Lin GL, Wood LS, Inema I, Miller SE, Bieri G, Zuchero JB, et al. 2014. Neuronal activity promotes oligodendrogenesis and adaptive myelination in the mammalian brain. Science 344: 1252304.

Gillespie CS, Sherman DL, Fleetwood-Walker SM, Cottrell DF, Tait S, Garry EM, Wallace VC, Ure J, Griffiths IR,
Smith A, et al. 2000. Peripheral demyelination and neuropathic pain behavior in periaxin-deficient mice. $\mathrm{Neu}$ ron 26: $523-531$.

Glenn TD, Talbot WS. 2013a. Analysis of Gpr126 function defines distinct mechanisms controlling the initiation and maturation of myelin. Development 140: 3167-3175.

Glenn TD, Talbot WS. 2013b. Signals regulating myelination in peripheral nerves and the Schwann cell response to injury. Curr Opin Neurobiol 23: 1041-1048.

Goebbels S, Oltrogge JH, Kemper R, Heilmann I, Bormuth I, Wolfer S, Wichert SP, Mobius W, Liu X, Lappe-Siefke C, et al. 2010. Elevated phosphatidylinositol 3,4,5-trisphosphate in glia triggers cell-autonomous membrane wrapping and myelination. J Neurosci 30: 8953-8964.

Goebbels S, Oltrogge JH, Wolfer S, Wieser GL, Nientiedt T, Pieper A, Ruhwedel T, Groszer M, Sereda MW, Nave K-A. 2012. Genetic disruption of Pten in a novel mouse model of tomaculous neuropathy. EMBO Mol Med 4: 486-499.

Goldstein B, Macara IG. 2007. The PAR proteins: Fundamental players in animal cell polarization. Dev Cell 13: 609-622.

Gould RM. 1977. Incorporation of glycoproteins into peripheral nerve myelin. J Cell Biol 75: 326-338.

Gould RM, Mattingly G. 1990. Regional localization of RNA and protein metabolism in Schwann cells in vivo. J Neurocytol 19: 285-301.

Gould RM, Oakley T, Goldstone JV, Dugas JC, Brady ST, Gow A. 2008. Myelin sheaths are formed with proteins that originated in vertebrate lineages. Neuron Glia Biol 4: $137-152$.

Grossmann KS, Wende H, Paul FE, Cheret C, Garratt AN, Zurborg S, Feinberg K, Besser D, Schulz H, Peles E, et al. 2009. The tyrosine phosphatase Shp2 (PTPN11) directs Neuregulin-1/ErbB signaling throughout Schwann cell development. Proc Natl Acad Sci 106: 16704-16709.

Grove M, Komiyama NH, Nave K-A, Grant SG, Sherman DL, Brophy PJ. 2007. FAK is required for axonal sorting by Schwann cells. J Cell Biol 176: $277-282$.

Guo L, Moon C, Zheng Y, Ratner N. 2013. Cdc42 regulates Schwann cell radial sorting and myelin sheath folding through NF2/merlin-dependent and independent signaling. Glia 61: 1906-1921.

Hall A. 2012. Rho family GTPases. Biochem Soc Trans 40: $1378-1382$.

Halter JA, Clark JW Jr. 1993. The influence of nodal constriction on conduction velocity in myelinated nerve fibers. Neuroreport 4: 89-92.

He Y, Kim JY, Dupree J, Tewari A, Melendez-Vasquez C, Svaren J, Casaccia P. 2010. Yy1 as a molecular link between neuregulin and transcriptional modulation of peripheral myelination. Nat Neurosci 13: 1472-1480.

Heasman SJ, Ridley AJ. 2008. Mammalian Rho GTPases: New insights into their functions from in vivo studies. Nat Rev Mol Cell Biol 9: 690-701.

Heath JW, Kidd GJ, Trapp BD, Dunkley PR. 1991. Myelin maintenance by Schwann cells in the absence of axons. Neurosci Lett 128: 277-280.

Heller BA, Ghidinelli M, Voelkl J, Einheber S, Smith R, Grund E, Morahan G, Chandler D, Kalaydjieva L, Giancotti F, et al. 2014. Functionally distinct PI 3-kinase path- 
J.L. Salzer

ways regulate myelination in the peripheral nervous system. J Cell Biol 204: 1219-1236.

Henry EW, Eicher EM, Sidman RL. 1991. The mouse mutation claw paw: Forelimb deformity and delayed myelination throughout the peripheral nervous system. J Hered 82: $287-294$.

Hildebrand C, Westerberg M, Mustafa GY. 1989. Influence of an experimental hindlimb maldevelopment on axon number and nodal spacing in the rat sciatic nerve. Brain Res Dev Brain Res 50: 169-175.

Hildebrand C, Bowe CM, Remahl IN. 1994. Myelination and myelin sheath remodelling in normal and pathological PNS nerve fibres. Prog Neurobiol 43: 85-141.

Hogl S, van Bebber F, Dislich B, Kuhn PH, Haass C, Schmid B, Lichtenthaler SF. 2013. Label-free quantitative analysis of the membrane proteome of Bacel protease knock-out zebrafish brains. Proteomics 13: 1519-1527.

Horiuchi K, Zhou HM, Kelly K, Manova K, Blobel CP. 2005. Evaluation of the contributions of ADAMs 9, 12, 15, 17, and 19 to heart development and ectodomain shedding of neuregulins $\beta 1$ and $\beta 2$. Dev Biol 283: 459-471.

Howe DG, McCarthy KD. 2000. Retroviral inhibition of cAMP-dependent protein kinase inhibits myelination but not Schwann cell mitosis stimulated by interaction with neurons. J Neurosci 20: 3513-3521.

Hu X, Hicks CW, He W, Wong P, Macklin WB, Trapp BD, Yan R. 2006. Bace1 modulates myelination in the central and peripheral nervous system. Nat Neurosci 9: 1520-1525.

Huijbregts RP, Roth KA, Schmidt RE, Carroll SL. 2003. Hypertrophic neuropathies and malignant peripheral nerve sheath tumors in transgenic mice overexpressing glial growth factor $\beta 3$ in myelinating Schwann cells. J Neurosci 23: 7269-7280.

Huynh JL, Casaccia P. 2013. Epigenetic mechanisms in multiple sclerosis: Implications for pathogenesis and treatment. Lancet Neurol 12: 195-206.

Jacob C, Christen CN, Pereira JA, Somandin C, Baggiolini A, Lotscher P, Ozcelik M, Tricaud N, Meijer D, Yamaguchi T, et al. 2011. HDAC1 and HDAC2 control the transcriptional program of myelination and the survival of Schwann cells. Nat Neurosci 14: 429-436.

Jaegle M, Ghazvini M, Mandemakers W, Piirsoo M, Driegen S, Levavasseur F, Raghoenath S, Grosveld F, Meijer D. 2003. The POU proteins Brn-2 and Oct-6 share important functions in Schwann cell development. Genes Dev 17: $1380-1391$.

* Jessen KR, Mirsky R, Lloyd AC. 2015. Schwann cells: Development and role in nerve repair. Cold Spring Harb Perspect Biol doi: 10.1101/cshperspect.a020487.

Jin J-J, Nikitin AY, Rajewsky MF. 1993. Schwann cell lineagespecific neu (erbB-2) gene expression in the developing rat nervous system. Cell Growth Diff 4: 227-237.

Jin F, Dong B, Georgiou J, Jiang Q, Zhang J, Bharioke A, Qiu F, Lommel S, Feltri ML, Wrabetz L, et al. 2011. N-WASp is required for Schwann cell cytoskeletal dynamics, normal myelin gene expression and peripheral nerve myelination. Development 138: 1329-1337.

Kao SC, Wu H, Xie J, Chang CP, Ranish JA, Graef IA, Crabtree GR. 2009. Calcineurin/NFAT signaling is required for neuregulin-regulated Schwann cell differentiation. Science 323: 651-654.
Kegel L, Aunin E, Meijer D, Bermingham JR. 2013. LGI proteins in the nervous system. ASN Neuro 5: 167-181.

Kidd GJ, Ohno N, Trapp BD. 2013. Biology of Schwann cells. Handb Clin Neurol 115: 55-79.

Kipanyula MJ, Woodhoo A, Rahman M, Payne D, Jessen KR, Mirsky R. 2013. Calcineurin-nuclear factor of activated T cells regulation of Krox-20 expression in Schwann cells requires elevation of intracellular cyclic AMP. J Neurosci Res 91: 105-115.

Koling A. 1985. Membrane architecture of myelinated nerve fibres in the human dental pulp studied by freeze-fracturing. Arch Oral Biol 30: 121-128.

La Marca R, Cerri F, Horiuchi K, Bachi A, Feltri ML, Wrabetz L, Blobel CP, Quattrini A, Salzer JL, Taveggia C. 2011. TACE (ADAM17) inhibits Schwann cell myelination. Nat Neurosci 14: 857-865.

Langley JN, Anderson HK. 1903. On the union of the fifth cervical nerve with the superior cervical ganglion. J Physiol 30: 439-442.

Laplante M, Sabatini DM. 2013. Regulation of mTORC1 and its impact on gene expression at a glance. J Cell Sci 126: $1713-1719$.

Lasek RJ, Gainer H, Barker JL. 1977. Cell-to-cell transfer of glial proteins to the squid giant axon. The glia-neuron protein transfer hypothesis. J Cell Biol 74: 501-523.

Lazarevic V, Zullo AJ, Schweitzer MN, Staton TL, Gallo EM, Crabtree GR, Glimcher LH. 2009. The gene encoding early growth response 2 , a target of the transcription factor NFAT, is required for the development and maturation of natural killer T cells. Nat Immunol 10: 306-313.

Le N, Nagarajan R, Wang JY, Araki T, Schmidt RE, Milbrandt J. 2005a. Analysis of congenital hypomyelinating Egr2Lo/ Lo nerves identifies Sox2 as an inhibitor of Schwann cell differentiation and myelination. Proc Natl Acad Sci 102: 2596-2601.

Le N, Nagarajan R, Wang JYT, Svaren J, LaPash C, Araki T, Schmidt RE, Milbrandt J. 2005b. Nab proteins are essential for peripheral nervous system myelination. Nat Neurosci 8: 932-940.

Lee Y, Morrison BM, Li Y, Lengacher S, Farah MH, Hoffman PN, Liu Y, Tsingalia A, Jin L, Zhang PW, et al. 2012. Oligodendroglia metabolically support axons and contribute to neurodegeneration. Nature 487: 443-448.

Lemmon MA, Schlessinger J. 2010. Cell signaling by receptor tyrosine kinases. Cell 141: 1117-1134.

Li S, Edgar D, Fassler R, Wadsworth W, Yurchenco PD. 2003. The role of laminin in embryonic cell polarization and tissue organization. Dev Cell 4: 613-624.

Liu J, Dietz K, DeLoyht JM, Pedre X, Kelkar D, Kaur J, Vialou V, Lobo MK, Dietz DM, Nestler EJ, et al. 2012. Impaired adult myelination in the prefrontal cortex of socially isolated mice. Nat Neurosci 15: 1621-1623.

Luo R, Jeong SJ, Jin Z, Strokes N, Li S, Piao X. 2011a. G protein-coupled receptor 56 and collagen III, a receptorligand pair, regulates cortical development and lamination. Proc Natl Acad Sci 108: 12925-12930.

Luo X, Prior M, He W, Hu X, Tang X, Shen W, Yadav S, Kiryu-Seo S, Miller R, Trapp BD, et al. 2011b. Cleavage of neuregulin-1 by BACE1 or ADAM10 protein produces differential effects on myelination. J Biol Chem 286: 23967-23974. 
Madrid RE, Jaros E, Cullen MJ, Bradley WG. 1975. Genetically determined defect of Schwann cell basement membrane in dystrophic mouse. Nature 257: 319-321.

Makinodan M, Rosen KM, Ito S, Corfas G. 2012. A critical period for social experience-dependent oligodendrocyte maturation and myelination. Science 337: 1357-1360.

Martini R, Mohajeri MH, Kasper S, Giese KP, Schachner M. 1995. Mice doubly deficient in the genes for P0 and myelin basic protein show that both proteins contribute to the formation of the major dense line in peripheral nerve myelin. J Neurosci 15: 4488-4495.

Masaki T. 2012. Polarization and myelination in myelinating glia. ISRN Neurol 2012: 769412.

Masaki T, Matsumura K. 2010. Biological role of dystroglycan in Schwann cell function and its implications in peripheral nervous system diseases. J Biomed Biotechnol 2010: 740403.

Matthews MA. 1968. An electron microscopic study of the relationship between axon diameter and the initiation of myelin production in the peripheral nervous system. Anat Rec 161: 337-352.

Maurel P, Salzer JL. 2000. Axonal regulation of Schwann cell proliferation and survival and the initial events of myelination requires PI 3-kinase activity. J Neurosci 20: 4635 4645.

Maurel P, Einheber S, Galinska J, Thaker P, Lam I, Rubin MB, Scherer SS, Murakami Y, Gutmann DH, Salzer JL. 2007. Nectin-like proteins mediate axon Schwann cell interactions along the internode and are essential for myelination. J Cell Biol 178: 861-874.

McKee KK, Yang DH, Patel R, Chen ZL, Strickland S, Takagi J, Sekiguchi K, Yurchenco PD. 2012. Schwann cell myelination requires integration of laminin activities. J Cell Sci 125: 4609-4619.

Mei L, Xiong WC. 2008. Neuregulin 1 in neural development, synaptic plasticity and schizophrenia. Nat Rev Neurosci 9: 437-452.

Melendez-Vasquez CV, Einheber S, Salzer JL. 2004. Rho kinase regulates Schwann cell myelination and formation of associated axonal domains. J Neurosci 24: 3953-3963.

Michailov GV, Sereda MW, Brinkmann BG, Fischer TM, Haug B, Birchmeier C, Role L, Lai C, Schwab MH, Nave K-A. 2004. Axonal neuregulin-1 regulates myelin sheath thickness. Science 304: 700-703.

Mikol DD, Hong HL, Cheng HL, Feldman EL. 1999. Caveolin-1 expression in Schwann cells. Glia 27: 39-52.

Mogha A, Benesh AE, Patra C, Engel FB, Schoneberg T, Liebscher I, Monk KR. 2013. Gpr126 functions in Schwann cells to control differentiation and myelination via G-protein activation. J Neurosci 33: 17976-17985.

Monje PV, Soto J, Bacallao K, Wood PM. 2010. Schwann cell dedifferentiation is independent of mitogenic signaling and uncoupled to proliferation: Role of cAMP and JNK in the maintenance of the differentiated state. J Biol Chem 285: 31024-31036.

Monk KR, Naylor SG, Glenn TD, Mercurio S, Perlin JR, Dominguez C, Moens CB, Talbot WS. 2009. A G protein-coupled receptor is essential for Schwann cells to initiate myelination. Science 325: 1402-1405.

Montani L, Buerki-Thurnherr T, de Faria JP, Pereira JA, Dias NG, Fernandes R, Goncalves AF, Braun A, Benninger Y,
Bottcher RT, et al. 2014. Profilin 1 is required for peripheral nervous system myelination. Development 141: $1553-1561$.

Monuki ES, Weinmaster G, Kuhn R, Lemke G. 1989. SCIP: A glial POU domain gene regulated by cyclic AMP. Neuron 3: 783-793.

Morton PD, Dellarole A, Theus MH, Walters WM, Berge SS, Bethea JR. 2013. Activation of NF- $\mathrm{KB}$ in Schwann cells is dispensable for myelination in vivo. J Neurosci 33: 9932 9936.

Mugnaini E, Osen KK, Schnapp B, Friedrich VL Jr. 1977. Distribution of Schwann cell cytoplasm and plasmalemmal vesicles (caveolae) in peripheral myelin sheaths. An electron microscopic study with thin sections and freezefracturing. J Neurocytol 6: 647-668.

Murray MA. 1968. An electron microscopic study of the relationship between axon diameter and the initiation of myelin production in the peripheral nervous system. Anat Rec 161: 337-352.

Nagata-Ohashi K, Ohta Y, Goto K, Chiba S, Mori R, Nishita M, Ohashi K, Kousaka K, Iwamatsu A, Niwa R, et al. 2004. A pathway of neuregulin-induced activation of cofilin-phosphatase Slingshot and cofilin in lamellipodia. J Cell Biol 165: 465-471.

Nans A, Einheber S, Salzer JL, Stokes DL. 2011. Electron tomography of paranodal septate-like junctions and the associated axonal and glial cytoskeletons in the central nervous system. J Neurosci Res 89: 310-319.

Napoli I, Noon LA, Ribeiro S, Kerai AP, Parrinello S, Rosenberg LH, Collins MJ, Harrisingh MC, White IJ, Woodhoo A, et al. 2012. A central role for the ERK-signaling pathway in controlling Schwann cell plasticity and peripheral nerve regeneration in vivo. Neuron 73: 729-742.

Nave K-A. 2010. Myelination and the trophic support of long axons. Nat Rev Neurosci 11: 275-283.

Nave K-A, Salzer JL. 2006. Axonal regulation of myelination by neuregulin 1. Curr Opin Neurobiol 16: 492-500.

Ness JK, Snyder KM, Tapinos N. 2013. Lck tyrosine kinase mediates $\beta 1$-integrin signalling to regulate Schwann cell migration and myelination. Nat Commun 4: 1912.

Newbern J, Birchmeier C. 2010. Nrg1/ErbB signaling networks in Schwann cell development and myelination. Semin Cell Dev Biol 21: 922-928.

Newbern JM, Li X, Shoemaker SE, Zhou J, Zhong J, Wu Y, Bonder D, Hollenback S, Coppola G, Geschwind DH, et al. 2011. Specific functions for ERK/MAPK signaling during PNS development. Neuron 69: 91-105.

Nickols JC, Valentine W, Kanwal S, Carter BD. 2003. Activation of the transcription factor NF- $\kappa$ B in Schwann cells is required for peripheral myelin formation. Nat Neurosci 6: $161-167$.

Nishino J, Saunders TL, Sagane K, Morrison SJ. 2010. Lgi4 promotes the proliferation and differentiation of glial lineage cells throughout the developing peripheral nervous system. J Neurosci 30: 15228-15240.

Nodari A, Zambroni D, Quattrini A, Court FA, D'Urso A, Recchia A, Tybulewicz VL, Wrabetz L, Feltri ML. 2007. Beta1 integrin activates Racl in Schwann cells to generate radial lamellae during axonal sorting and myelination. J Cell Biol 177: 1063-1075. 
Noseda R, Belin S, Piguet F, Vaccari I, Scarlino S, Brambilla P, Martinelli Boneschi F, Feltri ML, Wrabetz L, Quattrini A, et al. 2013. DDIT4/REDD1/RTP801 is a novel negative regulator of Schwann cell myelination. J Neurosci 33: 15295-15305.

Novak N, Bar V, Sabanay H, Frechter S, Jaegle M, Snapper SB, Meijer D, Peles E. 2011. N-WASP is required fo membrane wrapping and myelination by Schwann cells. J Cell Biol 192: 243-250.

Ogata T, Yamamoto S, Nakamura K, Tanaka S. 2006. Signaling axis in Schwann cell proliferation and differentiation. Mol Neurobiol 33: 51-62.

Ogawa Y, Oses-Prieto J, Kim MY, Horresh I, Peles E, Burlingame AL, Trimmer JS, Meijer D, Rasband MN. 2010. ADAM22, a Kv1 channel-interacting protein, recruits membrane-associated guanylate kinases to juxtaparanodes of myelinated axons. J Neurosci 30: 1038-1048.

Ozcelik M, Cotter L, Jacob C, Pereira JA, Relvas JB, Suter U, Tricaud N. 2010. Pals1 is a major regulator of the epithelial-like polarization and the extension of the myelin sheath in peripheral nerves. J Neurosci 30: 4120-4131.

Ozkaynak E, Abello G, Jaegle M, van Berge L, Hamer D, Kegel L, Driegen S, Sagane K, Bermingham JR Jr, Meijer D. 2010. Adam22 is a major neuronal receptor for Lgi4mediated Schwann cell signaling. J Neurosci 30: $3857-$ 3864.

Parkinson DB, Bhaskaran A, Arthur-Farraj P, Noon LA, Woodhoo A, Lloyd AC, Feltri ML, Wrabetz L, Behrens A, Mirsky R, et al. 2008. c-Jun is a negative regulator of myelination. J Cell Biol 181: 625-637.

Patzig J, Jahn O, Tenzer S, Wichert SP, de MonasterioSchrader P, Rosfa S, Kuharev J, Yan K, Bormuth I, Bremer J, et al. 2011. Quantitative and integrative proteome analysis of peripheral nerve myelin identifies novel myelin proteins and candidate neuropathy loci. J Neurosci 31: 16369-16386.

Pedraza L, Huang JK, Colman DR. 2001. Organizing principles of the axoglial apparatus. Neuron 30: 335-344.

Pereira JA, Benninger Y, Baumann R, Goncalves AF, Ozcelik M, Thurnherr T, Tricaud N, Meijer D, Fassler R, Suter U, et al. 2009. Integrin-linked kinase is required for radial sorting of axons and Schwann cell remyelination in the peripheral nervous system. J Cell Biol 185: 147-161.

Pereira JA, Baumann R, Norrmen C, Somandin C, Miehe M, Jacob C, Luhmann T, Hall-Bozic H, Mantei N, Meijer D, et al. 2010. Dicer in Schwann cells is required for myelination and axonal integrity. J Neurosci 30: 6763-6775.

Pereira JA, Lebrun-Julien F, Suter U. 2012. Molecular mechanisms regulating myelination in the peripheral nervous system. Trends Neurosci 35: 123-134.

Peters A, Palay SL, Webster Hd. 1991. The fine structure of the nervous system. Oxford University Press, New York.

Poliak S, Matlis S, Ullmer C, Scherer SS, Peles E. 2002. Distinct claudins and associated PDZ proteins form different autotypic tight junctions in myelinating Schwann cells. J Cell Biol 159: 361-372.

Pollard TD, Borisy GG. 2003. Cellular motility driven by assembly and disassembly of actin filaments. Cell 112: 453-465.

Porrello E, Rivellini C, Dina G, Triolo D, Del Carro U, Ungaro D, Panattoni M, Feltri ML, Wrabetz L, Pardi R, et al.
2014. Jab1 regulates Schwann cell proliferation and axonal sorting through p27. J Exp Med 211: 29-43.

Previtali SC, Nodari A, Taveggia C, Pardini C, Dina G, Villa A, Wrabetz L, Quattrini A, Feltri ML. 2003. Expression of laminin receptors in Schwann cell differentiation: Evidence for distinct roles. J Neurosci 23: 5520-5530.

Price RL, Lasek RJ, Katz MJ. 1993. Neurofilaments assume a less random architecture at nodes and in other regions of axonal compression. Brain Res 607: 125-133.

Raphael AR, Lyons DA, Talbot WS. 2011. ErbB signaling has a role in radial sorting independent of Schwann cell number. Glia 59: 1047-1055.

* Rasband MN, Peles E. 2015. The nodes of Ranvier: Molecular assembly and maintenance. Cold Spring Harb Perspect Biol doi: 10.1101/cshperspect.a020495.

Rohatgi R, Ma L, Miki H, Lopez M, Kirchhausen T, Takenawa T, Kirschner MW. 1999. The interaction between NWASP and the Arp2/3 complex links Cdc42-dependent signals to actin assembly. Cell 97: 221-231.

Rossor AM, Polke JM, Houlden H, Reilly MM. 2013. Clinical implications of genetic advances in Charcot-MarieTooth disease. Nat Rev Neurol 9: 562-571.

Rushton WAH. 1951. A theory of the effects of fibre size in medullated nerve. J Physiol 115: 101.

Sagane K, Hayakawa K, Kai J, Hirohashi T, Takahashi E, Miyamoto N, Ino M, Oki T, Yamazaki K, Nagasu T. 2005. Ataxia and peripheral nerve hypomyelination in ADAM22-deficient mice. BMC Neurosci 6: 33 .

Saher G, Simons M. 2010. Cholesterol and myelin biogenesis. Subcell Biochem 51: 489-508.

Saher G, Quintes S, Mobius W, Wehr MC, Kramer-Albers EM, Brugger B, Nave K-A. 2009. Cholesterol regulates the endoplasmic reticulum exit of the major membrane protein P0 required for peripheral myelin compaction. J Neurosci 29: 6094-6104.

Saito F, Moore SA, Barresi R, Henry MD, Messing A, RossBarta SE, Cohn RD, Williamson RA, Sluka KA, Sherman DL, et al. 2003. Unique role of dystroglycan in peripheral nerve myelination, nodal structure, and sodium channel stabilization. Neuron 38: 747-758.

Salzer JL. 1995. Mechanisms of adhesion between axons and glial cells. In The axon (ed. Waxman S, Kocsis J, Stys P), pp. 164-184. Oxford University Press, New York.

Salzer JL. 2003. Polarized domains of myelinated axons. Neuron 40: 297-318.

Salzer JL. 2012. Axonal regulation of Schwann cell ensheathment and myelination. J Peripher Nerv Syst 17: 14-19.

Salzer JL, Brophy PJ, Peles E. 2008. Molecular domains of myelinated axons in the peripheral nervous system. Glia 56: $1532-1540$.

Samara C, Poirot O, Domenech-Estevez E, Chrast R. 2013. Neuronal activity in the hub of extrasynaptic Schwann cell-axon interactions. Front Cell Neurosci 7: 228.

Scherer S, Salzer J. 2001. Axon-Schwann cell interactions during peripheral nerve degeneration and regeneration. In Glial cell development (ed. Jessen K, Richardson WD), pp. 299-330. Oxford University Press, London.

Shapiro L, Doyle JP, Hensley P, Colman DR, Hendrickson WA. 1996. Crystal structure of the extracellular domain from $\mathrm{P} 0$, the major structural protein of peripheral nerve myelin. Neuron 17: 435-449. 
Sheean ME, McShane E, Cheret C, Walcher J, Muller T, Wulf-Goldenberg A, Hoelper S, Garratt AN, Kruger M, Rajewsky K, et al. 2014. Activation of MAPK overrides the termination of myelin growth and replaces $\mathrm{Nrg1} / \mathrm{ErbB} 3$ signals during Schwann cell development and myelination. Genes Dev 28: 290-303.

Sherman DL, Krols M, Wu LM, Grove M, Nave K-A, Gangloff YG, Brophy PJ. 2012a. Arrest of myelination and reduced axon growth when Schwann cells lack mTOR. J Neurosci 32: 1817-1825.

Sherman DL, Wu LM, Grove M, Gillespie CS, Brophy PJ. 2012b. Drp2 and periaxin form Cajal bands with dystroglycan but have distinct roles in Schwann cell growth. J Neurosci 32: 9419-9428.

Shin YK, Jang SY, Park SY, Park JY, Kim JK, Kim JP, Suh DJ, Lee HJ, Park HT. 2014. Grb2-associated binder-1 is required for neuregulin-1-induced peripheral nerve myelination. J Neurosci 34: 7657-7662.

Shirakabe K, Wakatsuki S, Kurisaki T, Fujisawa-Sehara A. 2001. Roles of Meltrin $\beta$ /ADAM19 in the processing of neuregulin. J Biol Chem 276: 9352-9358.

* Simons M, Nave K-A. 2015. Oligodendrocytes: Myelination and axonal support. Cold Spring Harb Perspect Biol doi: 10.1101/cshperspect.a020479.

Simpson AH, Gillingwater TH, Anderson H, Cottrell D, Sherman DL, Ribchester RR, Brophy PJ. 2013. Effect of limb lengthening on internodal length and conduction velocity of peripheral nerve. J Neurosci 33: 4536-4539.

Small JR, Ghabriel MN, Allt G. 1987. The development of Schmidt-Lanterman incisures: An electron microscope study. J Anat 150: 277-286.

Snaidero N, Mobius W, Czopka T, Hekking LH, Mathisen C, Verkleij D, Goebbels S, Edgar J, Merkler D, Lyons DA, et al. 2014. Myelin membrane wrapping of CNS axons by $\mathrm{PI}(3,4,5) \mathrm{P} 3$-dependent polarized growth at the inner tongue. Cell 156: 277-290.

Sotelo JR, Canclini L, Kun A, Sotelo-Silveira JR, Xu L, Wallrabe H, Calliari A, Rosso G, Cal K, Mercer JA. 2013. Myosin-Va-dependent cell-to-cell transfer of RNA from Schwann cells to axons. PLoS ONE 8: e61905.

Sparrow N, Manetti ME, Bott M, Fabianac T, Petrilli A, Bates ML, Bunge MB, Lambert S, Fernandez-Valle C. 2012. The actin-severing protein cofilin is downstream of neuregulin signaling and is essential for Schwann cell myelination. J Neurosci 32: 5284-5297.

Speidel C. 1964. In vitro studies of myelinated nerve fibers. Int Rev Cytol 16: 173-231.

Spencer PS, Weinberg HJ. 1978. Axonal specification of Schwann cell expression and myelination. In Physiology and pathobiology of axons (ed. Waxman SG), pp. 389405. Raven, New York.

Spiegel I, Adamsky K, Eshed Y, Milo R, Sabanay H, SarigNadir O, Horresh I, Scherer SS, Rasband MN, Peles E. 2007. A central role for Necl4 (SynCAM4) in Schwann cell-axon interaction and myelination. Nat Neurosci 10: 861-869.

Stassart RM, Fledrich R, Velanac V, Brinkmann BG, Schwab MH, Meijer D, Sereda MW, Nave K-A. 2013. A role for Schwann cell-derived neuregulin-1 in remyelination. Nat Neurosci 16: 48-54.
Stevens B, Fields RD. 2000. Response of Schwann cells to action potentials in development. Science 287: 22672271.

Stevens B, Tanner S, Fields RD. 1998. Control of myelination by specific patterns of neural impulses. J Neurosci 18: 9303-9311.

Stewart HJ, Eccleston PA, Jessen KR, Mirsky R. 1991. Interaction between cAMP elevation, identified growth factors, and serum components in regulating Schwann cell growth. J Neurosci Res 30: 346-352.

Susuki K, Raphael AR, Ogawa Y, Stankewich MC, Peles E, Talbot WS, Rasband MN. 2011. Schwann cell spectrins modulate peripheral nerve myelination. Proc Natl Acad Sci 108: 8009-8014.

Suter U, Scherer SS. 2003. Disease mechanisms in inherited neuropathies. Nat Rev Neurosci 4: 714-726.

Svaren J, Meijer D. 2008. The molecular machinery of myelin gene transcription in Schwann cells. Glia 56: 1541 1551.

Tasken K, Aandahl EM. 2004. Localized effects of cAMP mediated by distinct routes of protein kinase A. Physiol Rev 84: 137-167.

Taveggia C, Zanazzi G, Petrylak A, Yano H, Rosenbluth J, Einheber S, Xu X, Esper RM, Loeb JA, Shrager P, et al. 2005. Neuregulin-1 type III determines the ensheathment fate of axons. Neuron 47: 681-694.

Terada N, Saitoh Y, Ohno N, Komada M, Saitoh S, Peles E, Ohno S. 2012. Essential function of protein 4.1G in targeting of membrane protein palmitoylated 6 into Schmidt-Lanterman incisures in myelinated nerves. Mol Cell Biol 32: 199-205.

Terada N, Saitoh Y, Ohno N, Komada M, Yamauchi J, Ohno S. 2013. Involvement of Src in the membrane skeletal complex, MPP6-4.1G, in Schmidt-Lanterman incisures of mouse myelinated nerve fibers in PNS. Histochem Cell Biol 140: 213-222.

Thurnherr T, Benninger Y, Wu X, Chrostek A, Krause SM, Nave K-A, Franklin RJ, Brakebusch C, Suter U, Relvas JB. 2006. Cdc42 and Rac1 signaling are both required for and act synergistically in the correct formation of myelin sheaths in the CNS. J Neurosci 26: 10110-10119.

Topilko P, Schneider-Maunoury S, Levi G, Baron-Van Evercooren A, Chennoufi AB, Seitanidou T, Babinet C, Charnay P. 1994. Krox-20 controls myelination in the peripheral nervous system. Nature 371: 796-799.

Toyama BH, Savas JN, Park SK, Harris MS, Ingolia NT, Yates JR 3rd, Hetzer MW. 2013. Identification of long-lived proteins reveals exceptional stability of essential cellular structures. Cell 154: 971-982.

Trapp BD, Andrews SB, Wong A, O'Connell M, Griffin JW. 1989. Co-localization of the myelin-associated glycoprotein and the microfilament components, F-actin and spectrin, in Schwann cells of myelinated nerve fibres. $J$ Neurocytol 18: 47-60.

Triolo D, Dina G, Taveggia C, Vaccari I, Porrello E, Rivellini C, Domi T, La Marca R, Cerri F, Bolino A, et al. 2012. Vimentin regulates peripheral nerve myelination. Development 139: 1359-1367.

Twiss JL, Fainzilber M. 2009. Ribosomes in axonsScrounging from the neighbors? Trends Cell Biol 19: 236-243. 
J.L. Salzer

Vallat JM, Sindou P, Preux PM, Tabaraud F, Milor AM, Couratier P, LeGuern E, Brice A. 1996. Ultrastructural PMP22 expression in inherited demyelinating neuropathies. Ann Neurol 39: 813-817.

Varon SS, Bunge RP. 1978. Trophic mechanisms in the peripheral nervous system. Annu Rev Neurosci 1: 327-361.

Viader A, Golden JP, Baloh RH, Schmidt RE, Hunter DA Milbrandt J. 2011. Schwann cell mitochondrial metabolism supports long-term axonal survival and peripheral nerve function. J Neurosci 31: 10128-10140.

Viader A, Sasaki Y, Kim S, Strickland A, Workman CS, Yang K, Gross RW, Milbrandt J. 2013. Aberrant Schwann cell lipid metabolism linked to mitochondrial deficits leads to axon degeneration and neuropathy. Neuron 77: 886898.

Vogl MR, Reiprich S, Kuspert M, Kosian T, Schrewe H, Nave K-A, Wegner M. 2013. Sox10 cooperates with the mediator subunit 12 during terminal differentiation of myelinating glia. J Neurosci 33: 6679-6690.

Voyvodic JT. 1989. Target size regulates calibre and myelination of sympathetic axons. Nature 342: 430-433.

Waegh SMd, Lee VM-Y, Brady ST. 1992. Local modulation of neurofilament phosphorylation, axonal caliber, and slow axonal transport by myelinating Schwann cells. Cell 68: 451-463.

Walko G, Wogenstein KL, Winter L, Fischer I, Feltri ML, Wiche G. 2013. Stabilization of the dystroglycan complex in Cajal bands of myelinating Schwann cells through plectin-mediated anchorage to vimentin filaments. Glia 61: $1274-1287$.

Wallquist W, Plantman S, Thams S, Thyboll J, Kortesmaa J, Lannergren J, Domogatskaya A, Ogren SO, Risling M, Hammarberg $\mathrm{H}$, et al. 2005. Impeded interaction between Schwann cells and axons in the absence of laminin $\alpha 4$. J Neurosci 25: 3692-3700.

Wang H, Tewari A, Einheber S, Salzer JL, Melendez-Vasquez CV. 2008. Myosin II has distinct functions in PNS and CNS myelin sheath formation. J Cell Biol 182: 11711184 .

Waxman SG. 1980. Determinants of conduction velocity in myelinated nerve fibers. Muscle Nerve 3: 141-150.

Webster HD. 1971. The geometry of peripheral myelin sheaths during their formation and growth in rat sciatic nerves. J Cell Biol 48: 348-367.

Wedel MJ. 2011. A monument of inefficiency: The presumed course of the recurrent laryngeal nerve in sauropod dinosaurs. Acta Palaeontol Pol 57: 251-256.

Weider M, Kuspert M, Bischof M, Vogl MR, Hornig J, Loy K, Kosian T, Muller J, Hillgartner S, Tamm ER, et al.
2012. Chromatin-remodeling factor Brg1 is required for Schwann cell differentiation and myelination. Dev Cell 23: 193-201.

Weider M, Reiprich S, Wegner M. 2013. Sox appeal—Sox10 attracts epigenetic and transcriptional regulators in myelinating glia. Biol Chem 394: 1583-1593.

Willem M, Garratt AN, Novak B, Citron M, Kaufmann S, Rittger A, DeStrooper B, Saftig P, Birchmeier C, Haass C. 2006. Control of peripheral nerve myelination by the $\beta$ secretase BACE1. Science 314: 664-666.

Windebank AJ, Wood P, Bunge RP, Dyck PJ. 1985. Myelination determines the caliber of dorsal root ganglion neurons in culture. J Neurosci 5: 1563-1569.

Woodhoo A, Alonso MB, Droggiti A, Turmaine M, D'Antonio M, Parkinson DB, Wilton DK, Al-Shawi R, Simons P, Shen J, et al. 2009. Notch controls embryonic Schwann cell differentiation, postnatal myelination and adult plasticity. Nat Neurosci 12: 839-847.

Wu R, Jurek M, Sundarababu S, Weinstein DE. 2001. The POU gene Brn-5 is induced by neuregulin and is restricted to myelinating Schwann cells. Mol Cell Neurosci 17: 683-695.

Yang D, Bierman J, Tarumi YS, Zhong YP, Rangwala R, Proctor TM, Miyagoe-Suzuki Y, Takeda S, Miner JH, Sherman LS, et al. 2005. Coordinate control of axon defasciculation and myelination by laminin-2 and -8. J Cell Biol 168: 655-666.

Yin X, Crawford TO, Griffin JW, Tu P, Lee VM, Li C, Roder J, Trapp BD. 1998. Myelin-associated glycoprotein is a myelin signal that modulates the caliber of myelinated axons. J Neurosci 18: 1953-1962.

Young KM, Psachoulia K, Tripathi RB, Dunn SJ, Cossell L, Attwell D, Tohyama K, Richardson WD. 2013. Oligodendrocyte dynamics in the healthy adult CNS: Evidence for myelin remodeling. Neuron 77: 873-885.

Yun B, Anderegg A, Menichella D, Wrabetz L, Feltri ML, Awatramani R. 2010. MicroRNA-deficient Schwann cells display congenital hypomyelination. J Neurosci 30: $7722-7728$.

Zalc B, Goujet D, Colman D. 2008. The origin of the myelination program in vertebrates. Curr Biol 18: R511-R512.

Zanazzi G, Einheber S, Westreich R, Hannocks MJ, BedellHogan D, Marchionni MA, Salzer JL. 2001. Glial growth factor/neuregulin inhibits Schwann cell myelination and induces demyelination. J Cell Biol 152: 1289-1299.

Zimmermann H. 1996. Accumulation of synaptic vesicle proteins and cytoskeletal specializations at the peripheral node of Ranvier. Microsc Res Tech 34: 462-473. 


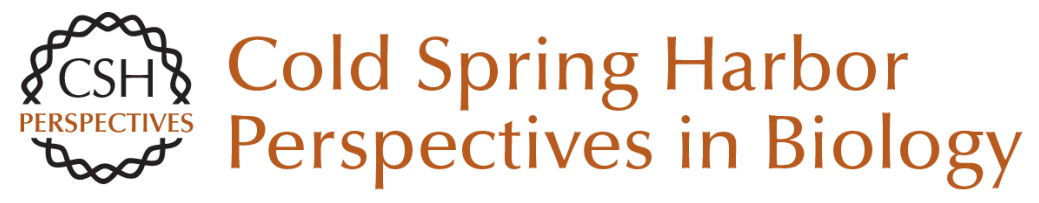

\section{Schwann Cell Myelination}

James L. Salzer

Cold Spring Harb Perspect Biol 2015; doi: 10.1101/cshperspect.a020529 originally published online June 8, 2015

\section{Subject Collection Glia}

The Nodes of Ranvier: Molecular Assembly and Maintenance

Matthew N. Rasband and Elior Peles

Microglia in Health and Disease

Richard M. Ransohoff and Joseph El Khoury

The Astrocyte: Powerhouse and Recycling Center Bruno Weber and L. Felipe Barros

Microglia Function in Central Nervous System

Development and Plasticity

Dorothy P. Schafer and Beth Stevens

Transcriptional and Epigenetic Regulation of Oligodendrocyte Development and Myelination in the Central Nervous System

Ben Emery and Q. Richard Lu

Origin of Microglia: Current Concepts and Past

Controversies

Florent Ginhoux and Marco Prinz

Glia Disease and Repair--Remyelination

Robin J.M. Franklin and Steven A. Goldman

Astrocytes in Neurodegenerative Disease

Hemali Phatnani and Tom Maniatis
Oligodendrocyte Development and Plasticity Dwight E. Bergles and William D. Richardson

Oligodendrocytes: Myelination and Axonal

Support Mikael Simons and Klaus-Armin Nave

Drosophila Central Nervous System Glia Marc R. Freeman

Perisynaptic Schwann Cells at the Neuromuscular

Synapse: Adaptable, Multitasking Glial Cells Chien-Ping Ko and Richard Robitaille

Astrocytes Control Synapse Formation, Function, and Elimination Won-Suk Chung, Nicola J. Allen and Cagla Eroglu

Schwann Cell Myelination James L. Salzer

Schwann Cells: Development and Role in Nerve Repair

Kristján R. Jessen, Rhona Mirsky and Alison C. Lloyd

Perineurial Glia

Sarah Kucenas

For additional articles in this collection, see http://cshperspectives.cshlp.org/cgi/collection/

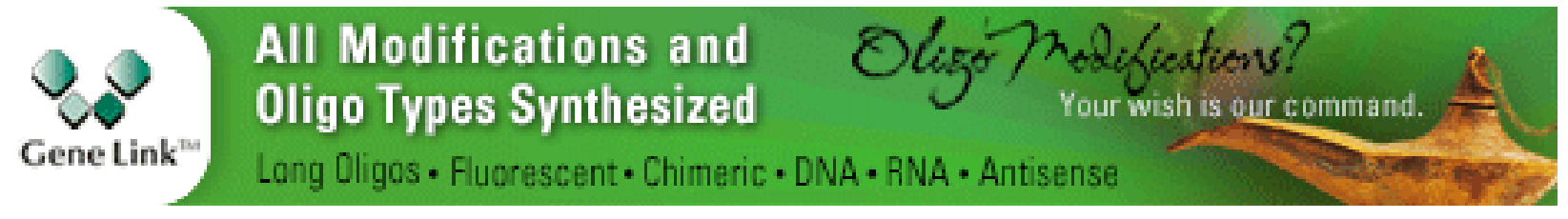

Copyright @ 2015 Cold Spring Harbor Laboratory Press; all rights reserved 